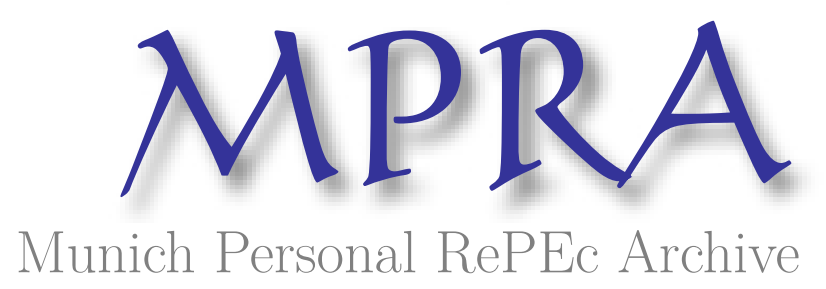

\title{
The rise and fall of universal banking: ups and downs of a sample of large and complex financial institutions since the late ' 90 s
}

Masciantonio, Sergio and Tiseno, Andrea

Banca d'Italia

October 2012

Online at https://mpra.ub.uni-muenchen.de/42494/

MPRA Paper No. 42494, posted 07 Nov 2012 15:49 UTC 


\title{
The Rise and Fall of Universal Banking: ups and downs of a sample of large and complex financial institutions since the late $\mathbf{6 0 0 \mathrm { s }}$
}

\author{
Sergio Masciantonio ${ }^{\mathrm{a}, \mathrm{b}}$ and Andrea Tiseno ${ }^{\mathrm{a}}$
}

October 2012

\begin{abstract}
We document the development of the major international banks since the late nineties, analysing balance sheet data for 27 large and complex financial institutions. We argue that balance sheet expansion and business line diversification paved the way to the rise of the universal banking model. This model, apparently sound and efficient in the run-up to the crisis, showed all its shortcomings when the crisis erupted. European banks highlighted greater fragilities in their business models. Moreover the changed financial and regulatory landscape that followed has challenged this model further. Many proposed remedies to the global financial crisis appear to push for a return of a narrower model for banking activity. The first evidence we detected through a set of panel regressions shows that the proposed remedies are likely to change the profitability and riskiness profile of the banking industry, pushing towards a safer, although less profitable, business model. Moreover, the contemporaneous effort by banks to move in this direction is likely to strengthen this shift.
\end{abstract}

JEL classification: G21, G01

Keywords: banks, banking crises, financial crises, balance sheets

\section{Contents}

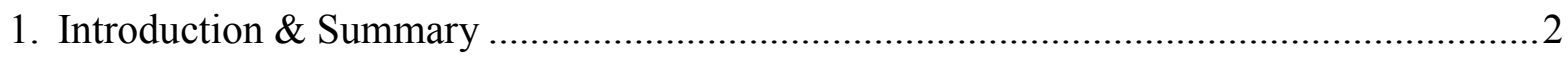

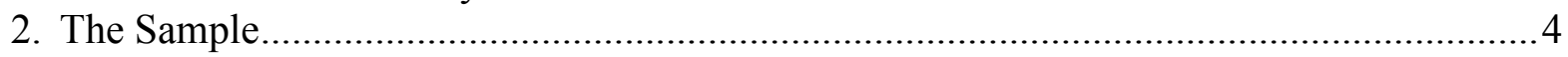

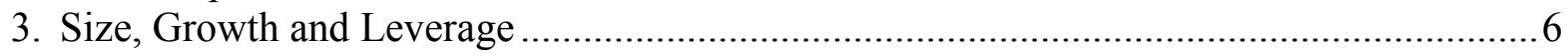

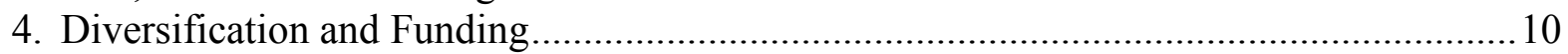

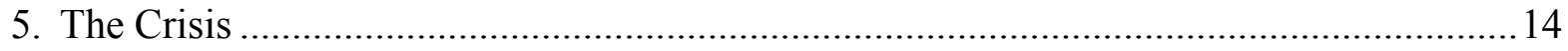

6. The Response to the Crisis: The Return to Traditional Banking?...................................20

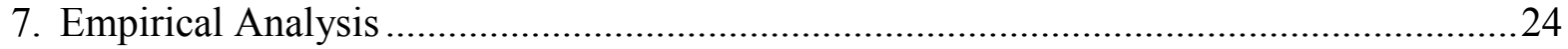

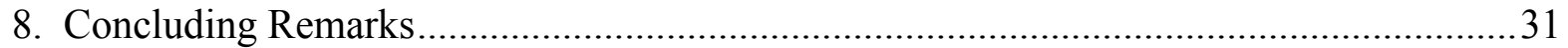

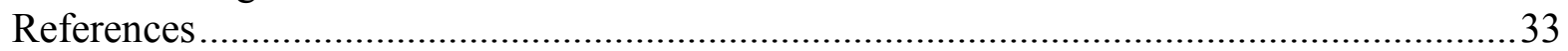

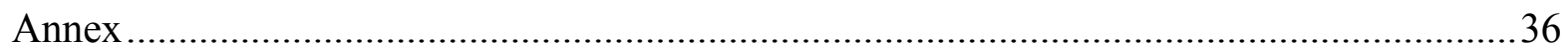

${ }^{\text {a }}$ Bank of Italy, Economic Outlook and Monetary Policy Department, Financial Analysis Division. We thank Giuseppe Grande, Aviram Levy, Marcello Pericoli and Andrea Zaghini for useful comments and suggestions. All remaining errors are our own. The opinions expressed in this paper are those of the authors and do not necessarily reflect those of the Bank of Italy.

${ }^{\mathrm{b}}$ Corresponding author. E-mail: sergio.masciantonio@bancaditalia.it 


\section{Introduction \& Summary}

The deregulation of the banking sector that started in the 1980s has blurred the borders between traditional and investment banking, paving the way for the birth of so-called universal banks, which are involved in any kind of banking and financial activity (De Grauwe (2008)). This process gained momentum from the end of the 1990s, thanks to several additional factors: the liberalization of capital flows that had started in the previous decade, changes in accounting and regulatory standards, the rise in cross-border banking activities.

As a result, the transformation of the banking sector since the late nineties has been significant and rapid, with several consequences still subject to investigation. Particularly, the global financial crisis, begun in 2007, has proved to be a major break-point in universal banking activity and performance. Its impact and legacy are still unfolding and are worth to be analysed in details. Moreover the state of the broader economy is deeply intertwined with the state of the banking sector. Global banks enhance the international transmission of shocks though their activities, contributing to more integrated global business cycles (Goldberg, 2009).

The purpose of this paper is to document some stylized facts concerning the transformation of the sector and to draw some evidence about the future prospects of the industry. In this light, relying on an econometric analysis, we try to ascertain the impact on the industry of the main regulatory changes being enforced in response to the global financial crisis. We follow the developments of the balance sheets of the largest banks in Europe and North America over the last decade. The reason to restrict our analysis to large banks is that these have experienced more radical changes compared with small, savings or regional banks. In fact, the former had the size to compete in an increasingly globalized and integrated financial system, and had a more appropriate structure to react quickly to regulatory changes and financial innovation and to compete against banks with different business models. Smaller banks were less affected by this evolutionary path. Moreover, the largest banks typically feature among those that are deemed to be systemic. Hence, we chose a sample of 27 large (or most important, in our judgement) banks, still on business at the end of 2011. Given the massive degree of financial innovation during the last decade and its deep impact on banks' activities, the label Large and Complex Financial Institutions (LCFI) looks particularly well-chosen for these institutions.

From our analysis we can sum-up the following stylized facts up to the run-up to crisis in the summer of 2007:

- Banks' balance sheets have grown to excessive sizes, relative to their home countries' GDP. This is particularly true for European banks, where the financial 
system is more bank-based. The growth of balance sheets was impressive in the run-up to the global financial crisis, stepping back only a little in more recent years.

- Leverage has grown massively, fuelling asset growth, to change direction during the crisis years. The consolidation that occurred throughout the period under examination was another main factor behind total assets growth.

- The massive debt-fuelled asset growth supported the expansion of retail and universal banks' activities in fields traditionally pertaining to investment banks, providing more revenues, but also more risks.

- Maturity mismatches and funding risk have also grown in the run-up to crisis. European banks, more reliant than their North-American counterparts on wholesale funding proved to be more exposed to these risks. The investment bank funding model, more reliant on short-term funding, was also prone to these risks.

- During the boom years, these developments led to an ever-increasing profitability (as measured by ROE).

Since 2007, as the crisis broke, things have changed swiftly. We can sum up the following stylized facts for the crisis years:

- Profitability dropped sharply and turned negative for several quarters, showing all the fragilities embedded in banks' balance sheets, which came out of the crisis severely weakened. The surge and then fall of profitability was sharper for European banks. Profitability then recovered only to a fraction of its pre-crisis level.

- The losses experienced by banks emerged via three main channels. First, losses arose from the lending activity connected to the slump in the housing market, especially in the US, and the global recession in 2009. Secondly, trading activity once the golden goose of universal banking - suffered enormous losses, affecting almost every bank. Thirdly, an unprecedented level of extraordinary losses, connected with large write-downs and exceptional activities, was experienced.

- The sovereign debt crisis severely affected European banks, which showed a weaker pace of recovery than their North-American peers.

- Deleveraging is one of the main challenges banks have faced in the aftermath of the crisis. In fact, banks' undercapitalization - coupled with excessive asset growth was identified as one of the main weaknesses. Thus the bulk of regulatory efforts concentrated on strengthening capital bases. 
- The harms to interbank markets and the liquidity crunch created the scope for increased amounts of liquidity held in banks' balance sheets.

Taken together, these features are putting the universal banking model under serious stress. Making the banking system safer might be inconsistent with the return to pre-crisis profitability levels. In this view, US, UK and EU authorities identified the excessive risk-taking beneath trading activity as one of the main threats to banking stability and proposed - in various forms the separation of investment banking from retail banking. This could even mark the end of the universal banking model as it took form during the 2000s.

The empirical evidence shows that the measures currently under way do have an impact on the current business model. As expected, while these measures can prove successful in containing the riskiness of the banking business, they are likely to decrease profitability at the same time. Moreover, the banking industry is trying to comply with these new measures contemporaneously, creating an interesting system-wide effect, leading to a further impact on riskiness and profitability. Since banks will certainly adapt to this new financial and regulatory landscape, there is room for further relevant developments in the banking business.

The paper is structured as follows. Section 2 describes the sample. In Section 3 we illustrate the path of LCFIs growth in size and leverage, while in Section 4 we describe the increased activity diversification and the funding model. Section 5 analyzes the impact of the crisis on banking activity and profitability. Section 6 describes the main legacies of the crisis. Section 7 provides an econometric analysis of these legacies effects on banking riskiness and profitability. Section 8 concludes.

\section{The Sample}

We selected a sample of 27 banks, aiming to encompass all the "most important" large and complex financial institutions from Europe and North America, active throughout the decade and still on business at the end of 2011 (cfr. Table 1). The first criterion adopted in our selection process was bank size, measured by its total assets, at the end of 2011. Among the banks listed we dropped Fannie Mae and Freddie Mac, even if sometimes considered as bank-like institutions, given their peculiar mortgage-based business model and their nature of government-sponsored enterprises (GSE). As a second criterion, all the insurance companies with a minor banking arm were excluded from the sample (i.e. AXA, Allianz, Metlife, etc.). Thus the only financial institution considered in the sample with a relevant insurance arm is the Dutch ING Groep. Finally, given the significance of investment banking activity because of its higher riskiness 
profile, we chose to include in the sample two smaller financial institutions, mainly focused on investment banking: Natixis and Bank of New York Mellon ${ }^{1}$ (see Annex 1 for a chart of banks total assets, risk weighted assets and total common equity).

Table 1. List of selected LFCI and their assets at the end of the financial year 2011

\begin{tabular}{|c|c|c|}
\hline Bank & Country & $\begin{array}{c}\text { Total Assets } \\
(€ \text { bln. })\end{array}$ \\
\hline BNP Paribas & France & 1,989 \\
\hline HSBC & UK & 1,964 \\
\hline Deutsche Bank & Germany & 1,897 \\
\hline Barclays & UK & 1,736 \\
\hline Royal Bank of Scotland & UK & 1,689 \\
\hline Bank of America & USA & 1,615 \\
\hline Credit Agricole SA & France & 1,588 \\
\hline JP Morgan & USA & 1,579 \\
\hline Citigroup & USA & 1,401 \\
\hline ING Groep & Netherlands & 1,238 \\
\hline Banco Santander & Spain & 1,200 \\
\hline Lloyds Banking Group & UK & 1,152 \\
\hline Societé Générale & France & 1,127 \\
\hline UBS AG & Switzerland & 1,046 \\
\hline Wells Fargo & USA & 938 \\
\hline Unicredit & Italy & 918 \\
\hline Credit Suisse Group AG & Switzerland & 818 \\
\hline Commerzbank & Germany & 751 \\
\hline Nordea Bank AB & Sweden & 719 \\
\hline Goldman Sachs & USA & 675 \\
\hline Intesa San Paolo & Italy & 653 \\
\hline Morgan Stanley & USA & 602 \\
\hline BBVA & Spain & 591 \\
\hline Dexia & Belgium & 564 \\
\hline Royal Bank of Canada & Canada & 542 \\
\hline Natixis & France & 455 \\
\hline Bank of New York Mellon & USA & 184 \\
\hline
\end{tabular}

Source: Datastream.

Note: where end of 2011 data not available, data from 2011 Q3 appear.

Our datasource is Bloomberg. Given the relatively short time-span (1998-2011), we use quarterly data, which are reported on a yearly basis in order to get rid of seasonal effects ${ }^{2}$. When quarterly data are not available (most of English and French banks publish their financial statements semi-annually with only a few figures published quarterly), missing data are imputed with the econometric methodology outlined in the appendix (see Annex 2).

\footnotetext{
${ }^{1}$ It's interesting to notice that our sample is very close to the sample of G-SIFIs selected by the FSB in cooperation with the BIS (for further details see: "Policy measures to address systemically important financial institutions (SIFIs)", FSB, November 2011). Since our analysis is restricted to European and North American banks, the only G-SIFI we are not considering is State Street. Another G-SIFI, Banque Populaire CdE, is the parent company of Natixis. Thus is somehow included in our sample. Our sample however is richer, including three non-G-SIFI banks: Intesa San Paolo, BBVA and Royal Bank of Canada.

${ }^{2}$ Quarterly flows data are presented on a yearly basis calculating the trailing sum of the last four quarters data. Thus data of 1999:Q1 accounts also for results of 1998.
} 
Excluding data for bankrupt banks, like Lehman Brothers, might distort our data. This might be even more true choosing - as we did - not to consolidate banks balance sheets backwards, with their acquired peers. As a matter of facts, this can lead to an overestimation of the financial performance of our sample. Moreover, our data represent a far smaller share of the market, especially considering the first years of the decade. However this kind of sample offers a bright picture of the growing importance of this group of financial institutions in the global financial system, given their growing market share. Moreover the analysis of the financial results of what proved to be the best-performing financial institutions up to now, can give a deeper insight of the best practices in the field and what went wrong during the global financial crisis started in 2007.

\section{Size, Growth and Leverage}

Banks' size grew massively during recent years, mainly through the increase of leverage and consolidation of the sector. The changes have been sharper for European banks. Our sample includes 8 North American (7 from the U.S.) and 19 European banks (12 from the Eurozone). Even if the largest American banks are similar in size to the largest European banks, there is a striking difference when assets size is compared with the GDP of the home country. The level of total assets of many European banks exceeds - or is very close - to the GDP level of their countries, whereas American banks' total assets are far lower than their country's GDP. This difference comes from the bigger role that banks have in the European financial system, which is certainly more bank-based than the American one. Thus American banks occupy a far smaller role in their financial system, than their European counterparts. European banks appear too big with respect to the size of their home countries. It might be more plausible to relate European banks to the size of the European Union, since the reference horizon of European banks' activity spans the whole continent. In this case, European banks' size is much more similar to their North-American peers. However, even if things might change soon, EU still lacks a common bankruptcy policy, supervisory authority and deposit insurance policy in order to be compared with the US, and a common monetary policy is a duty of only a sub-sample of EU countries.

Many of these banks turned into universal banks during the period under review, expanding their activities in several fields, and consequently their balance sheets size. The rise of universal banking can be explained through the deregulation of the banking sector during the 1990s. In Europe, the approval of the Second Banking Directive (which came into effect in 1993), endorsed the principle of universal banking, allowing "credit institutions" to engage in any financial activity, and removed the obstacles to cross-border banking (Benink and Benston (2005)). 
Similarly the repeal of the six-decade old Glass-Steagall act in 1999, allowed American banks to conduct almost any financial activity (Barth el al. (2000)). A brief survey of the other main drivers of development in the banking sector can be found in Panetta et al (2009a).

This deregulation led to a considerable growth of banks. However, the growth of total assets for European banks in our sample has been far larger than for their North-American counterparts (Chart 1, left-hand panel). This massive growth affected more or less the whole sample of European banks, with UK and Swiss banks ahead of all others. Interestingly, the UK and Switzerland are the two countries where the ratio of banking assets to GDP is highest, and where the banking sector was most severely affected during the crisis of 2007-2008. This is not surprising as they are the largest financial hubs of the European economy.

\section{Chart 1. Growth of banks' size}

Total assets and foreign claims $(\$ \operatorname{tn}$.

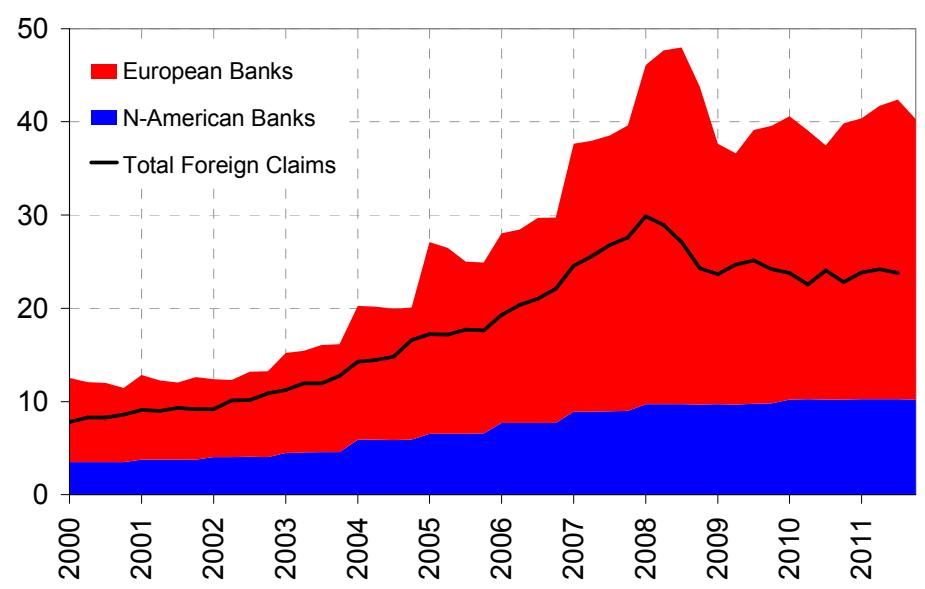

Source: Datastream, BIS and authors' calculations

Note: Total Foreign Claims are intended for the whole banking system, while total assets are computed only for the banks of the sample

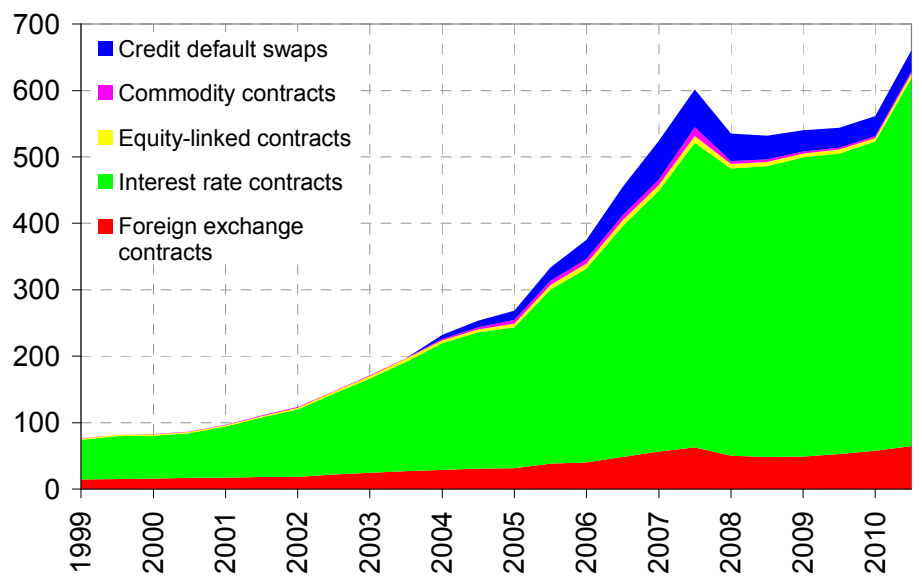

Source: BIS

Note: Outstanding notional amount is considered

As can be seen from Chart 1 (left-hand panel), 2008 had been a turning year in asset growth for European banks, with their total level of assets averaging 30 \$ trillions at the end of 2011 down from a peak of 38 trillions in 2008 Q2. Understanding the main drivers of this enormous growth is certainly important. Probably, globalization and the increased financial integration particularly important inside the EU after the introduction of the euro - played a non-negligible role as can be seen by the growth path of foreign claims for the banking sector as a whole during the same period ${ }^{3}$. In fact, at the end of 2011, all the banks in the sample can be considered truly "global" banks, as they operate under several jurisdictions. Some of them, like HSBC or Banco

\footnotetext{
${ }^{3}$ Foreign Claims, in the BIS definition, are calculated as the sum of banks' cross-border claims, local claims of foreign affiliates in foreign and local currencies. For further information see "Guideline to the International Consolidated Banking Statistics”, Bank for International Settlements, 2012.
} 
Santander, have more than two thirds of their activities outside their home countries and several other banks have a relevant share of their business located in emerging markets. The increase in cross-border banking and the rise of interconnectedness, particularly in Europe, proved a hard challenge to deal with for the several national supervisory authorities.

The expansion of banks' balance sheets coincided with the ballooning of the derivatives market (Chart 1, right-hand panel). The growth path of the amount outstanding of OTC derivatives during the decade is strikingly similar to the path followed by banking assets. Although among American banks we have a larger share of pure investment banks - always more involved in financial engineering - financial innovation is likely to have deeply affected most banks of the sample. As previously noted, growth in derivatives dealership was surely fostered by banking sector deregulation.

Given the main drivers of the enormous growth of the banks included in our sample, it's not less important to investigate how this process unfolded. Regardless of the retained earnings policy - traditionally a minor channel of asset growth - two main channels arise: growth through increased leverage or through increased concentration (that is, through M\&A). Even if these two channels partially overlap - given the role of LBO in M\&A activity - especially before the crisis erupted, their distinct role plainly emerges from the data.

\section{Chart 2. Increase in leverage and consolidation}

\section{Leverage}

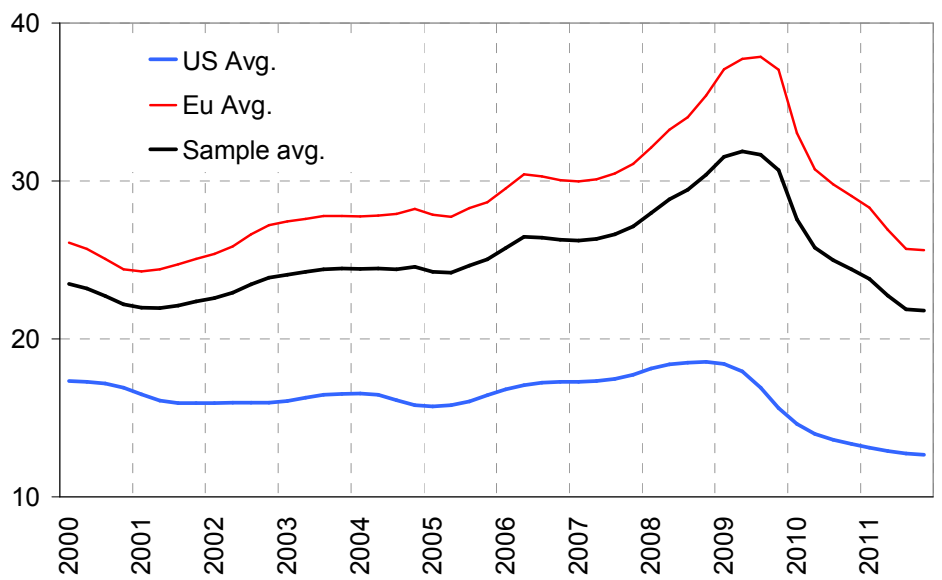

Source: Authors' calculations on Bloomberg data

Note: Leverage calculated as the ratio between total assets and total common equity for each bank, then, mean values are calculated with the single-bank leverage data. Quarterly data (annualized via the trailing sum of the last 4 quarters for every observation).

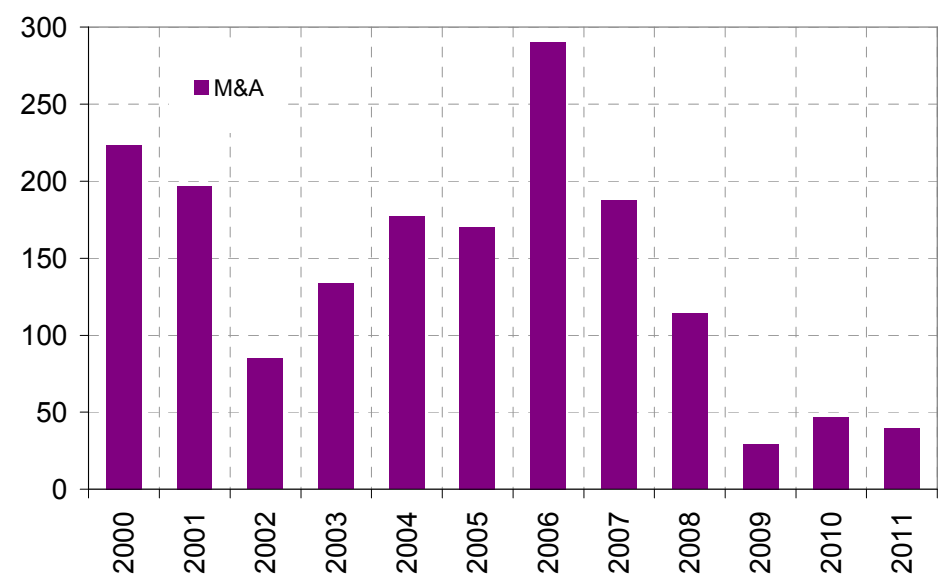

Source: Authors' calculation on Thomson Reuters data

Note: M\&A Operations within the financial sector in Belgium, Canada, France, Germany, Italy, Netherlands, Spain, Sweden, Switzerland, UK, USA.

The leverage ratio - calculated as the ratio between total assets and total common equity grew almost uninterruptedly from 2000, when it stood at 22 for the entire sample, to early 2009 reaching the record level of 32 (see Chart 2). Thus we can well conclude that at least part of the 
asset growth relied on an increase in leverage. Moreover a closer look at the two subsamples suggests some more insights. Although the curves for European and North-American banks are not easily comparable, given the different accounting standards in use in Europe and North America, we can overall find at least some important differences ${ }^{4}$. In fact the leverage ratio for North American banks remained fairly stable through the first half of the decade, to increase only very slightly in 2007 and 2008. On the contrary, European leverage ratio experienced an impressive growth to a maximum level of 38 in 2009, and with some banks (i.e. Deutsche Bank, Commerzbank, Société Générale, Lloyds Banking Group) showing an overall level well above 50, at their peaks. Then it is fairly straightforward to consider the growth-through-leverage a typical European phenomenon, rather than American. There's also a lag-effect on leverage, with its ratio increasing even during 2008 and 2009, due to the erosion of the capital base following the losses experienced during the crisis. Many banks entered the crisis overleveraged. However the massive deleveraging begun in 2009 interested both subsamples with roughly the same intensity, reaching, at the end of 2011, a minimum compared to the beginning of the decade. The path of the leverage ratio during the decade is broadly consistent with the pro-cyclicality of leverage detected by Adrian and Shin (2011). As we will see in greater detail ahead, one of the main causes behind the reduction of leverage is the increase in capital requirements, a strongly supported measure among others - by supervisory authorities after the collapse of Lehman Brothers in 2008.

Analogously, M\&A activity within the financial sector was buoyant in the pre-crisis years (see Chart 2, right-handed panel). As Group of Ten (2001) pointed out, the level of M\&A started to increase during the nineties, with a relevant acceleration in the last years of that decade. However, the level of cross-border M\&A was limited. After a loss of momentum at the beginning of the 2000s, the increase in yearly M\&A activity had been impressive between 2002 and 2006; with the total value of 2006 M\&A operations being almost four-fold its 2002 value. Its contribution to the increase in size of the banks of the sample was certainly crucial as had been crucial in increasing their concentration. In fact most of the banks of the sample undertook at least one major M\&A operation in the period 2000-2007. However, it has to be noted that the buoyant M\&A activity of the 2000s mainly involved European banks. In fact, North-American banks experienced the most intense phase of consolidation during the late nineties, with a coherent growth in total assets. This fact can explain why, during the last decade, the growth of their total assets had been much slower that their European peers. The eruption of the crisis, in mid-2007,

\footnotetext{
${ }^{4}$ In Europe, where IFRS are in use, balance sheets appear larger than in North America, where US GAAP are in use. The main difference between these two accounting standards regards derivatives positions: where IFRS rule that derivatives positions must be accounted for their long and short positions in financial statements, US GAAP allow to let figure in financial statements only the netting of the derivatives positions held.
} 
wiped-off most of the activity, which sharply declined in 2008 and 2009 and stabilized to a subdued level below $€ 50$ billions. Moreover, many operations finalized during the crisis years, rather than being driven by profitability, were fostered by efforts, from monetary and supervision authorities, to bail-out severely weakened financial institutions.

\section{Diversification and Funding}

The expansion of banks' balance sheets coincided with increasing diversification in banking activity and in the funding model. Traditionally retail banking relied mainly on interest income, commonly considered the most stable source of income, whereas the typical investment banking source of income comes from the trading activity and commissions and fees revenues. However, boundaries between different activities became increasingly blurred during the period, with almost every bank of the sample involved in any type of banking and financial activity.

Chart 3, left-handed panel, shows the average revenues decomposition, by component, for the whole sample. Revenues are shown as a percentage of operating costs (thus giving also a rough idea of the efficiency of the banking activity during the 2000s). Interest income remained fairly stable, around an average value of $65 \%$ of total operating costs, until 2007 Q2. During the same period revenues from trading activity and commission and fees steadily increased. However the role of interest income grew enormously when the crisis broke, peaking at a maximum level of $82 \%$ of operating costs in the first half of 2009 , probably thanks to central banks interventions in response to the crisis. At the same time income from trading activity, which grew enormously until 2007 - from an average level of around $16 \%$ in 2002 to a peak of $41 \%$ in early 2007 - turned to a loss for various quarters (e.g. $-10 \%$ in 2008 Q4), to recover only from the third quarter of 2009 but remaining well below the pre-crisis level. Commissions and fees income, decreased slightly, from $58 \%$ pre-crisis to $51 \%$, mainly because of the slowdown in economic activity and the lower financial activity requested by non-financial corporations. Interestingly the "other income" component - usually a residual component - gradually increased its contribution from the end of 2010 , until a peak of $18 \%$ of operating costs at the end of 2011 . This increase might be explained by the extraordinary operations, undertaken mainly by European banks, to boost their capital base and fulfil the new and more binding capital requirements, through the sale of nonstrategic assets. Summing up, total revenues grew to $173 \%$ of operating costs in 2007 Q2, mainly thanks to non-interest based income; then they sharply decreased to a minimum of $136 \%$ in 2008 Q4, because of the stiff decline in the same components. The recovery that followed from its minimum was interrupted again in 2011 Q1, mainly because of the heightening of the sovereign 
debt crisis in the Eurozone, because of the compression of the margins in almost every income component.

\section{Chart 3. Diversification in banking activity \\ Operating income decomposition}

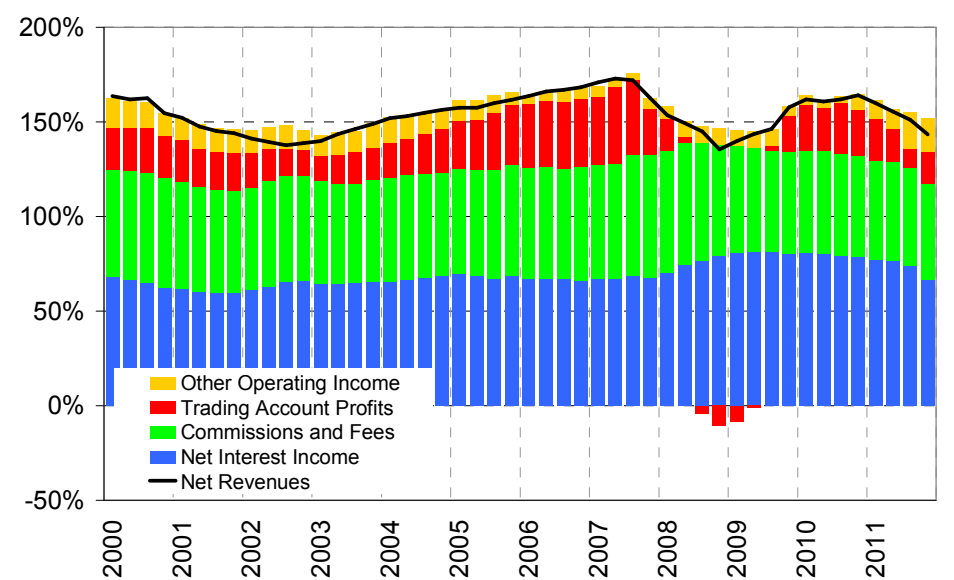

Source: Authors' calculations on Bloomberg data

Note: Net Revenues (Total Income) to Total Operating Costs Ratio. Total Income is then decomposed into: Net Interest Income (blue area), Commissions and Fees (Green), Trading and Account Profits (Red) and Other Income (Yellow). Quarterly data (annualized via the trailing sum of the last 4 quarters for every observation).

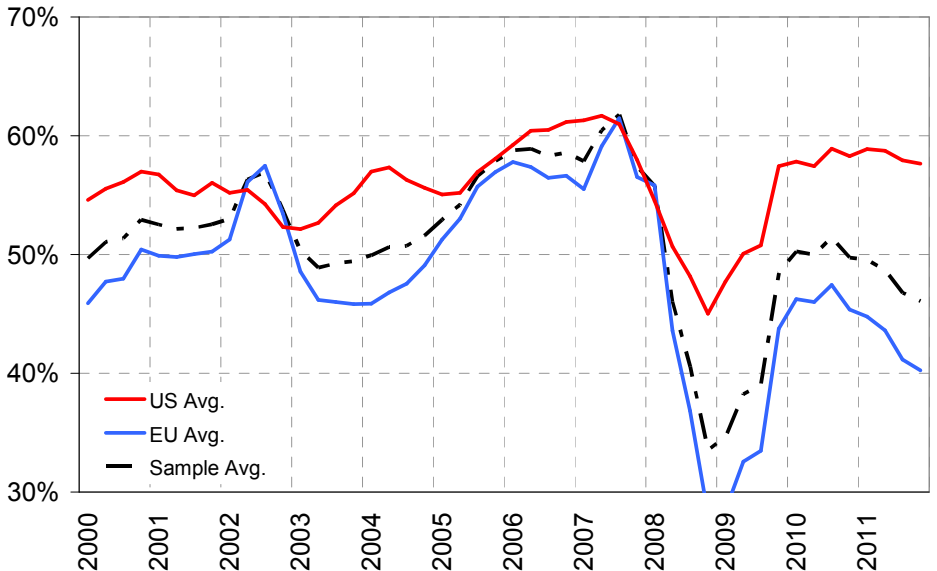

Source: Authors' calculation on Bloomberg data

Note: The share of non-interest revenues is calculated as the ratio between the sum of trading profits and commissions and fees, and total revenues for each bank, then, mean values are calculated with the single-bank share of non-interest revenues data. Quarterly data (annualized via the trailing sum of the last 4 quarters for every observation). To enhance the insight of the graph, the scale of the y-axis has been restricted, even if it cuts off some relevant values of the figures.

The share of non-interest income, usually coming from investment banking activity, in total revenues has increased in the period under review (Chart 3, right-handed panel). The banks of the sample increased their operations in more volatile - and more profitable - non-interest based activities from $50 \%$ of total revenues to more than $60 \%$ on the brink of the crisis. Given the increase in non-interest income, the contribution of interest income to total revenues slightly decreased in terms of the other components, as noted by Davies et al. (2010) for the UK banking sector. As explained before, the sharp drop in non-interest revenues, experienced in 2007-2009, does not stand for a curb in these activities but in a decrease of their contribution to total revenues due to increased volatility in financial markets and slowing economic activity. Interestingly, the increase in non-interest revenues in 2000-2007 had been sharper and more volatile for European banks, which originally gathered most of their revenues from interest-based activity. On the other hand, the sub-group of North-American banks, more investment banking oriented, showed a higher share of revenues coming from non-interest activities throughout the decade. This share also remained more stable than for European banks. Moreover, after the crisis, North-American banks recovered more quickly, with the 2010-2011 share of non-interest income broadly in line with its pre-crisis level. European banks, facing the heightening of the sovereign debt crisis, were not able to completely recover to the pre-crisis level of non-interest income. On the contrary, their 
share of non-interest income dropped again from 2010, highlighting an increasing difference with their North-American peers.

Table 2. Sample decomposition by prevailing type of activity

\begin{tabular}{|l|l|l|}
\hline \multicolumn{1}{|c|}{ Retail banks } & \multicolumn{1}{|c|}{ Investment banks } & \multicolumn{1}{c|}{ Universal banks } \\
\hline HSBC & UBS AG & BNP Paribas \\
ING Groep & Credit Suisse Group AG & Deutsche Bank \\
Banco Santander & Goldman Sachs & Barclays \\
Wells Fargo & Morgan Stanley & Royal Bank of Scotland \\
Unicredit & Natixis & Bank of America \\
Commerzbank & Bank of New York Mellon & Credit Agricole SA \\
Nordea Bank AB & & JP Morgan \\
Intesa San Paolo & & Citigroup \\
BBVA & & Lloyds Banking Group \\
Dexia & & Societé Générale \\
& & Royal Bank of Canada \\
\hline
\end{tabular}

Source: Authors' calculations on Bloomberg data

Note: The attribution to one of the three classes (retail, investment and universal banks) was done with the following rule: retail banks have, on average, a share of non-interest revenues below $40 \%$ of total revenues; investment banks have, on average, a share of non-interest revenues beyond $60 \%$ of total revenues; while universal banks have, on average, a share of non-interest revenues between $40 \%$ and $60 \%$ of total revenues.

The sample can be subdivided in three sub-groups by the degree of income diversification: mainly retail banks (10 banks), mainly investment banks (6) and truly universal banks (11), as shown in Table 2. Retail banks still rely mainly on interest income, while for investment banks interest income plays a minor role, with the bulk being trading and commissions; finally universal banks provide a high degree of diversification among the different sources of income (the income decomposition at single bank's level can be found in Annex 3). The increased diversification of activities can be ascribed to retail and universal banks. It had the primary objective to catch up with the higher level of profitability reached by investment banks. However this process led to an overall increase in those banks' riskier activity.

Loan-to-Asset Ratio

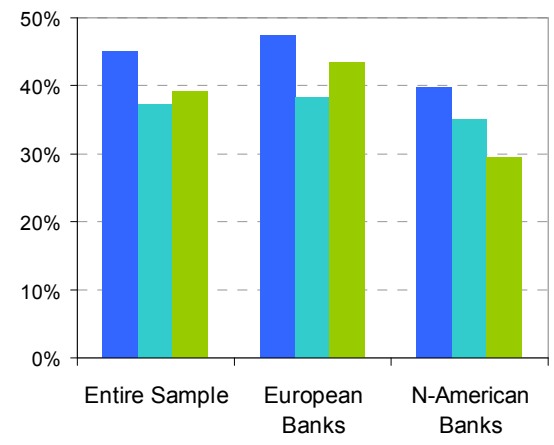

\section{Chart 4. Business Model}

Deposit-to-Asset Ratio

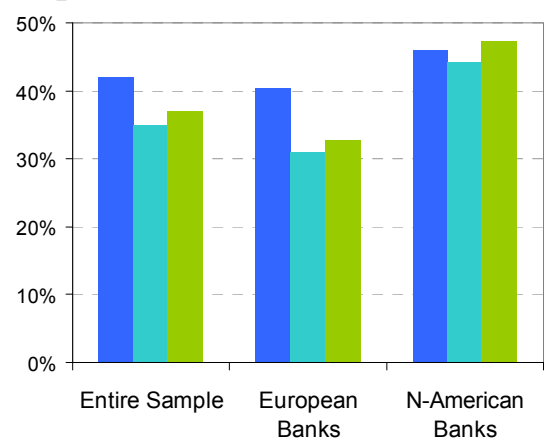

Loan-to-Deposit Ratio

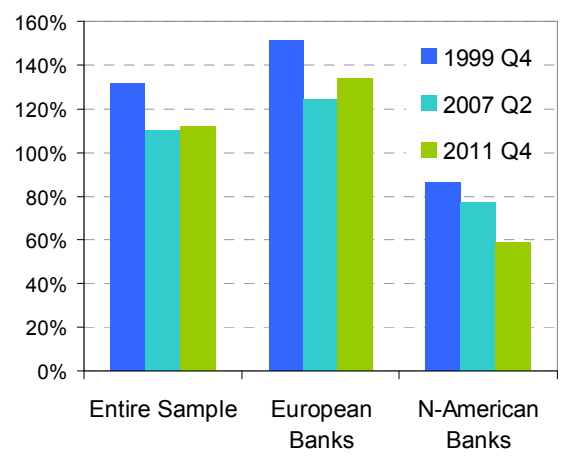

Source: Authors' calculations on Bloomberg data

Note: The three ratios are calculated for each bank, then averaged for every group. Quarterly data (annualized via the trailing sum of the last 4 quarters for every observation). 
Another significant difference between European and North-American banking activities can be detected through the analysis of the Loan-to-Asset Ratio, LAR (Chart 4 left-hand panel). It shows that loans have a far greater role in Europe than in North America. The LAR decreased constantly throughout the decade for North-American banks, standing below 30\% at the end of 2011. European banks instead rely for a larger part of their activities on loans. Even if the ratio decreased somewhat from 1999 to 2007, it increased again to a level near the beginning of the decade, at $43 \%$. This difference can be explained through the different structure of the American financial market, where GSEs account for a relevant share of real estate mortgages, the securitization is more common, and - thanks to a deeper corporate bond market - corporations usually turn to market-based debt.

Diversification of activity has been funded in different ways, with different impact on banks' business models. Considering funding (Chart 4 centre panel), the Deposit-to-Asset Ratio (DAR) which can be roughly considered as the reverse of the wholesale funding ratio - shows that European banks relied (and still rely) on customer deposits as a source of funding less than NorthAmerican banks. This difference, which was not extremely significant at the beginning of the decade (46\% vs 40\%), increased sharply, with the DAR decreasing to $33 \%$ for European banks, while increasing at $47 \%$ for North-American banks. This difference stands for a strikingly different funding model, with European banks increasingly reliant on wholesale funding, which is traditionally more volatile.

Considering the functional breakdown shown in Table 2, it is worth noting that investment banks usually relied only to a minor degree on customer deposits. Thus their funding model, more wholesale oriented, has always been less stable than their retail counterparts. Moreover investment banks covered a larger share of their funding needs with short-term funding, leading to a much riskier funding model.

Putting LAR and DAR together we can have a clearer picture, with the Loan-to-Deposit Ratio (LDR), shown in Chart 4 right-hand panel. This indicator is very important because wholesale funding is shorter-term and more volatile than customer deposits as a source of funding, and is obviously more volatile than loans which are usually long-term activities. Thus a high LDR exposes a bank to a high maturity mismatch and then, ultimately, to a high funding risk. Given the stability of loans and deposits the best business combination would yield a LDR beneath $100 \%$. However, European banks have always had an LDR above 100\%. It stood at $134 \%$ for the subgroup at the end of 2011, thus European banks seem ill-positioned to withstand sudden reversals in the wholesale funding market (i.e. as French banks, which usually more heavily relied on wholesale funding, had shown during the last quarter of 2011). North-American banks instead 
constantly lowered their LDR during the last decade, reaching a minimum of $59 \%$ at the end of 2011, exhibiting a much safer business model from this perspective.

\section{The Crisis}

The massive changes in the banking sector were rewarded by a growing profitability during the boom years. The main profitability indicator, ROE - calculated as the ratio between net income and total common equity - is shown in Chart 5. Profitability grew constantly for the whole sample from 2002 to 2007, even if North-American banks had always outperformed their European competitors. However the developing path of ROE for both sub-groups is broadly similar. After a sharp decline of profitability in 2000-2001, connected with the burst of the Dot.Com bubble, ROE grew uninterruptedly from a minimum in 2002 , until exceeding $20 \%$ at the onset of the global financial crisis. Then it declined sharply in $2008 / 2009$, to rebound only a little in 2010. During the pre-crisis years, ROE for North-American banks had always been higher than $10 \%$, whereas ROE for European banks, even reaching the same level around 20\% in 2006/2007, started from a far lower average level in 2002, just around 5\%. Thus European banks showed a greater surge in profitability in the few years preceding the crisis. Part of this increase in profitability was triggered by the increased diversification of banking activity, as shown in the previous paragraph (in accordance to Elsas et al. (2010)). This diversification was often oriented towards more risky and profitable activities. Probably, as Ongena and Peydrò (2011) point out, during the low interest rate period (from 2002 to 2005) banks relaxed their standards and undertook excessive risk-taking.

The excessive risk-taking and the excessive growth of leverage, together with low risk premia and volatilities and surging asset prices, were signals of a growing vulnerability of the banking sector, in spite of the high level of profitability (Borio (2010)). Moreover, at the beginning of the decade European banks - traditionally more retail-oriented - being less profitable than their North-American counterparts might have tried to catch-up by increasing more steeply their balance sheets' size through leverage and their investment banking operations (as shown in the previous paragraph). These features, having been implemented too quickly, might be at the root of the sharper decline in profitability experienced by European banks during the global financial crisis. ROE for European banks has shown also a far steeper decline during the crisis years, remaining negative on average for 4 quarters (2008:Q4 - 2009:Q3), while North-American banks managed to maintain a positive profitability in every quarter. 


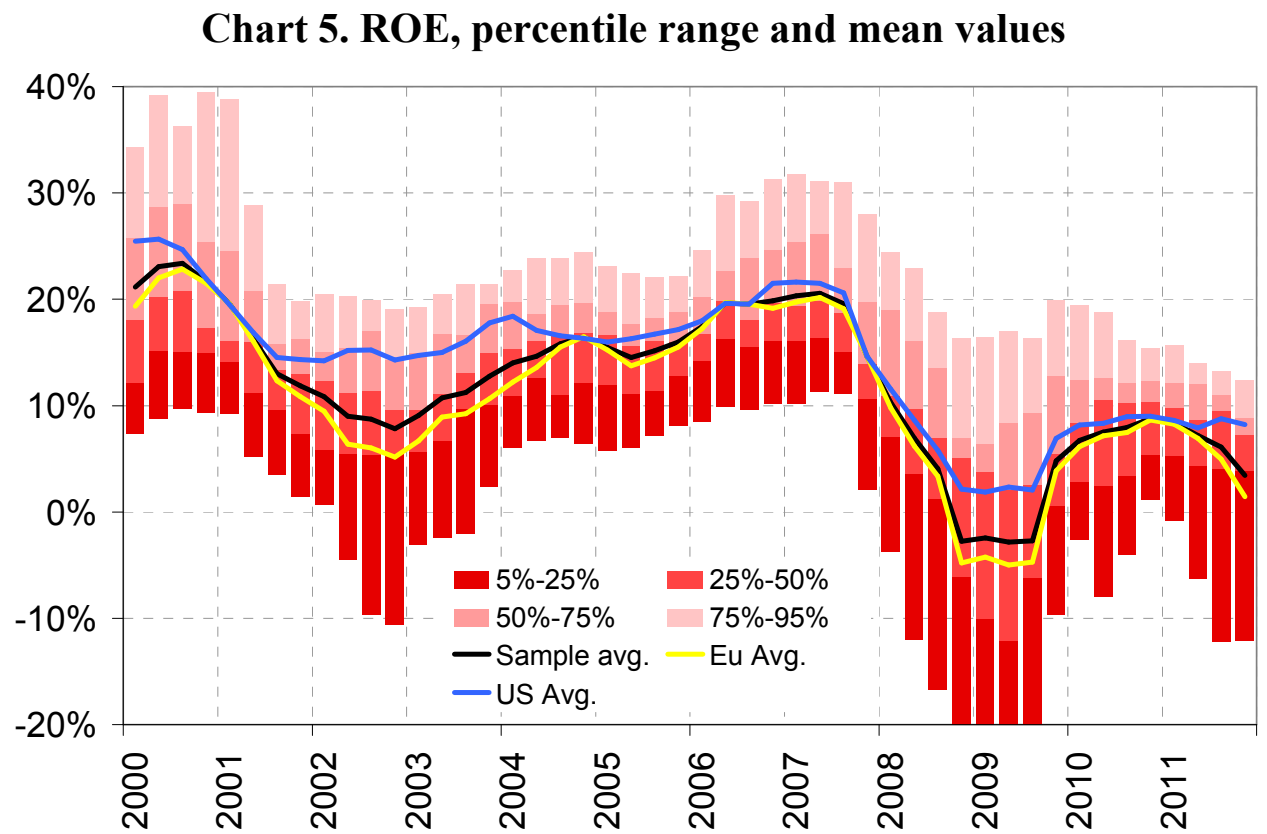

Source: Authors' calculations on Bloomberg data

Note: ROE calculated as the ratio between net income and total common equity for each bank, then, mean values are calculated with the singlebank ROE data. The percentile range distribution is also calculated on single-bank ROE data. Quarterly data (annualized via the trailing sum of the last 4 quarters for every observation). To enhance the insight of the graph, the scale of the y-axis has been restricted, even if it cuts off some relevant values of the figures.

The global financial crisis originated in the American housing market in the first half of 2007 , with the collapse of the subprime mortgage market ${ }^{5}$. Then, the freeze of the interbank money market led to a sudden spread of the crisis to the broader financial system through fire sales of toxic assets, collapsing values of almost any asset and huge losses which did not spared even the safest banks. The speed of transmission of the market tensions to the banking sector was favoured by the previously highlighted weaknesses, embedded in banks' balance sheets.

As the distribution in Chart 5 shows, the crisis years were characterized by an extreme heterogeneity, with some banks severely affected and accounting for a relevant part of the downward shift of ROE (Europe: UBS, Credit Suisse, RBS, Natixis; USA: Citigroup, Bank of America), while others managed to remain almost untouched.

The huge losses that affected banks during the crisis years appeared - and can be measured mainly through three channels, depending on their different nature:

- Provisions for loan losses, which come from the most typical banking activity, deeply connected with interest income;

- Trading losses, which come from the riskier and highly volatile non-interest activities and are closely associated to the diversification of bank activities during the boom years;

\footnotetext{
${ }^{5}$ For an historical perspective of the global financial crisis, sess Bordo (2008).
} 
- Extraordinary losses, which encompass all the non-operating or exceptional losses.

Provisions for loan losses account for realized and potential losses on the loan portfolio arisen during the reference quarter. As shown in Chart 6, the ratio of provisions for loan losses to total loans reached its maximum during the crisis, with a peak at 1,8\% in 2009:Q3, for the entire sample $^{6}$. Even having the same shape, the ratio for North-American banks, standing at $2.6 \%$ at its peak, had been massively higher than for European banks, with a maximum value of $1.4 \%$. It started this rapid rise before European banks, increased more, and then it also started to decrease more rapidly, while the ratio for European banks, after a slight decrease, stabilized around 0.9\% above its historical average. Interestingly the ratio for North-American banks, which has been traditionally higher than the one of their European peers, became lower for the first time since 2000 in 2011:Q4. This overtaking might reflect the possible end of the downward cycle in the American real estate market, while at the same time the weakness of the housing market in many European country (Spain, above all) is still harming the loan portfolio of several European banks.

\section{Chart 6. Provisions for Loan Losses (to total loans), percentile range and mean values}

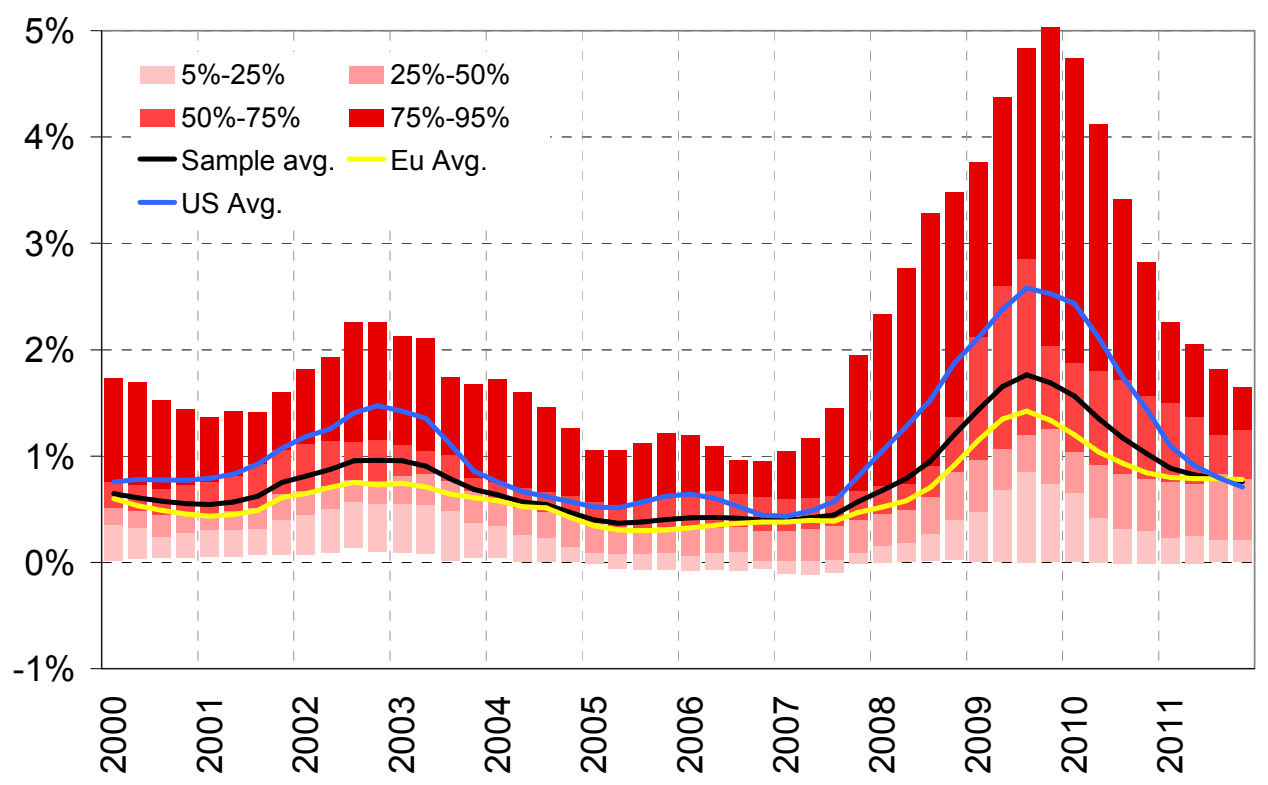

Source: Authors' calculations on Bloomberg data

Note: Values are calculated as the ratio between provisions for loan losses and total loans for each bank, then, mean values are calculated with the single-bank ratio data. The percentile range distribution is also calculated on single-bank ratio data. Quarterly data (annualized via the trailing sum of the last 4 quarters for every observation). To enhance the insight of the graph, the scale of the y-axis has been restricted, even if it cuts off some relevant values of the figures.

\footnotetext{
${ }^{6}$ Goldman Sachs and Morgan Stanley are not included in this ratio calculation, as they do not put aside provisions for loan losses.
} 
This interpretation gains support from Chart 7, where the ratio of non-performing assets to total assets is shown. The ratio for North-American banks started its decline in 2010:Q4, while the ratio for European banks still shows an increasing trend at the end of 2011, standing on its highest level on historical standards. Moreover the high degree of dispersion of the percentile range accounts for the worryingly high level of non-performing assets of many European banks, like Italian and Spanish ones. The speed that American banks showed in cleaning their balance sheets from non-performing assets might reflect both the end of the downward trend in the real estate sector and a greater efficiency, due to the US law, in renegotiating contracts on non-performing assets $^{7}$.

\section{Chart 7. Non-Performing Assets (to total assets), percentile range and mean values}

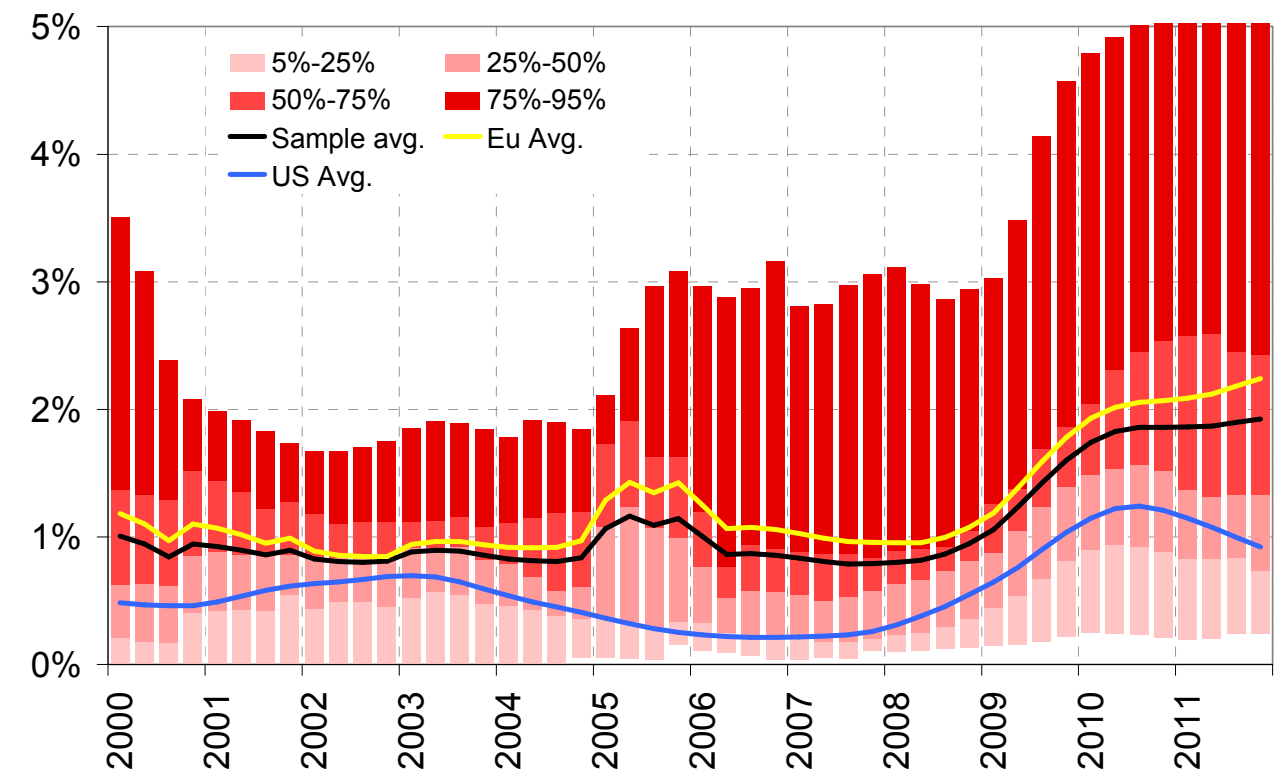

Source: Authors' calculations on Bloomberg data

Note: Values are calculated as the ratio between non-performing assets to total assets for each bank, then, mean values are calculated with the single-bank ratio data. The percentile range distribution is also calculated on single-bank ratio data. Quarterly data (annualized via the trailing sum of the last 4 quarters for every observation). To enhance the insight of the graph, the scale of the y-axis has been restricted, even if it cuts off some relevant values of the figures.

Considering profits and losses from trading activity (Chart 8) we detect a very similar pattern to ROE (see Chart 5 above). After a moderate decline at the beginning of the decade, the average ratio between trading profits and operating costs regularly rose from $13 \%$ in 2002 to a maximum of $41 \%$ in 2007:Q1, only few months before the crisis erupted. Moreover the whole distribution showed a massive increase in heterogeneity, with some banks (like Goldman Sachs, Lloyds Banking Group, Crédit Agricole) seeing their trading profits exceed 100\% of operating costs, while the most retail oriented banks maintained only a moderate share of their revenues coming

\footnotetext{
${ }^{7}$ In accordance with this view, considering the American housing market, Agarwal et al. (2010) describe the relative lower effectiveness of foreclosures and resolutions of mortgage contracts with respect to their renegotiation, under the terms of the Home Affordable Modification Program (HAMP), initiated in 2009.
} 
from trading activity. As retrospectively argued by several authors - Borio (2010), Brunnermeier (2008), Reinhart and Rogoff (2008a, 2008b) - the low interest rate and volatility environment prevalent before the crisis favoured asset bubbles and excessive risk-taking via "search-for-yield" behaviour and the like.

\section{Chart 8. Trading Profits (to Operating Costs), percentile range and mean values}

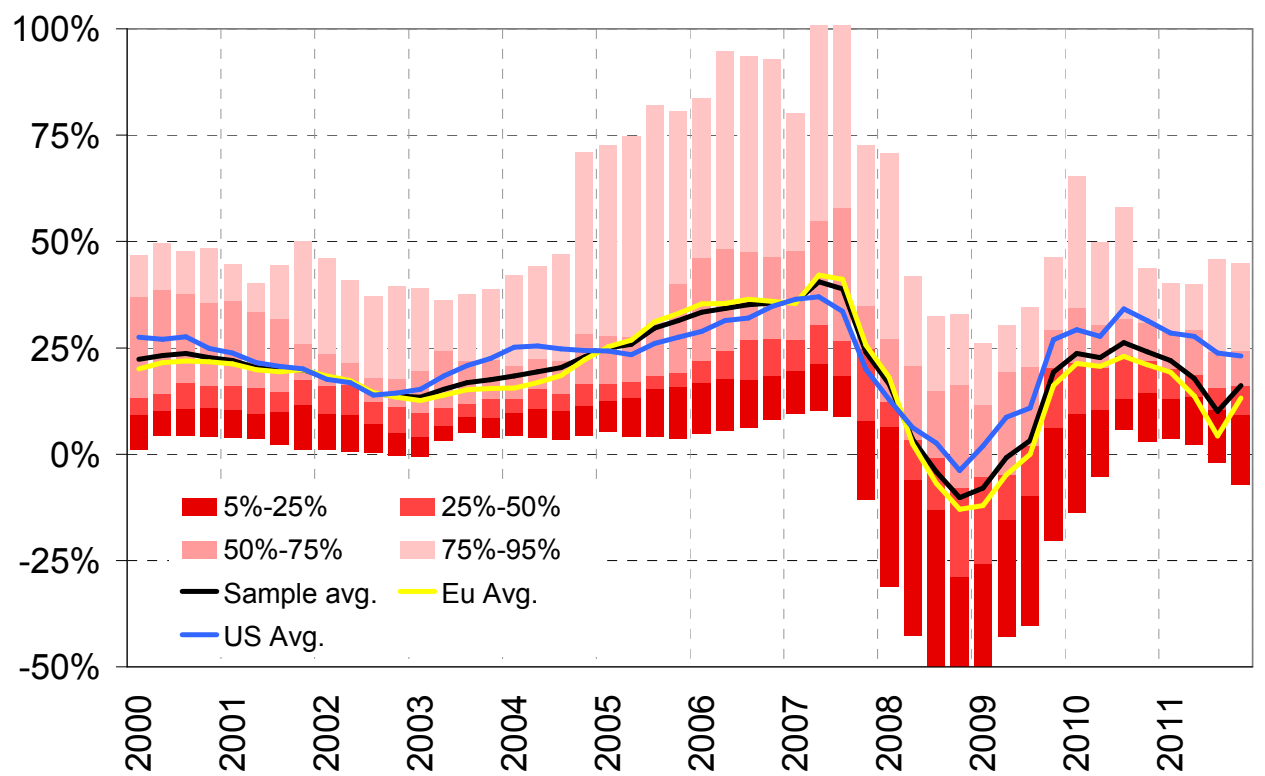

Source: Authors' calculations on Bloomberg data

Note: Values are calculated as the ratio between trading profits to operating costs for each bank, then, mean values are calculated with the singlebank ratio data. The percentile range distribution is also calculated on single-bank ratio data. Quarterly data (annualized via the trailing sum of the last 4 quarters for every observation). To enhance the insight of the graph, the scale of the y-axis has been restricted, even if it cuts off some relevant values of the figures.

From last quarter of 2007, the turmoil on financial markets started to severely affect trading activity with the average ratio sharply declining to a minimum value of $-10 \%$ in $2008: \mathrm{Q}$. Notably, as the distribution shows, the heterogeneity between banks results enormously increased during the most troubled quarters. In fact while some banks managed to maintain a decent share of profits from their trading activity, others recorded losses higher than $50 \%$ of operating costs. The most affected banks during the period (2007:Q4 - 2009:Q2) were of any kind: from investment banks (UBS, Credit Suisse, Natixis, etc.) to universal banks (Citigroup, RBS, Deutsche Bank etc.), to mostly retail banks (Unicredit, Intesa San Paolo, ING, etc.). The banks that suffered the largest losses during the crisis, still showed the lowest profitability of the banks of the sample during 2011 (above all, Citigroup and RBS). Moreover some of the most criticized merger between troubled banks and supposedly healthy banks (e.g. Merrill Lynch with Bank of America, Bear Sterns with JP Morgan, HBOS with Lloyds Banking Group) were finalized in consequence of the heavy trading losses of those turbulent quarters. The recovery originated in 2009 lost momentum at the end of 2010. However, trading profits of North-American banks stabilized at a level broadly 
in line with the pre-crisis level. European banks, suffering from the reversals in fixed-income trading activities, connected to the Sovereign Debt Crisis, experienced a decline of their trading profits in 2011, to level well beneath their North-American competitors. Interestingly, the banks that experienced the heaviest losses in 2011 were those mostly spared by the first phase of the global financial crisis, like Italian and French banks.

The third channel, conveying several different sources of losses after the ordinary activity, is given by extraordinary items arising from securitization activity, write-downs of assets, various types of impairments (e.g. goodwill impairments), abnormal losses (according to the ISO95 definition), restructuring charges, spin-off/sell-off expenses, etc. ${ }^{8}$. Chart 9 shows the ratio between the sums of all these extraordinary losses to total assets. Although the mean of the distribution does not show any particular spike, the percentiles show a tremendous increase in extraordinary losses from 2008:Q4. After a decline in 2010 the ratio of extraordinary losses to total assets started to climb again in 2011, mainly as a consequence of the goodwill impairments and write-downs of sovereign bonds holdings by European banks, in connection with the Sovereign Debt Crisis. It's interesting to point out that the bulk of these losses, from 2008, has been provided by NorthAmerican banks. However, in accordance with the previous two indicators (provisions for loan losses and trading profits), European banks suffered increasing heavier losses during 2011.

\section{Chart 9. Extraordinary Losses (to Total Assets), percentile range and mean values}

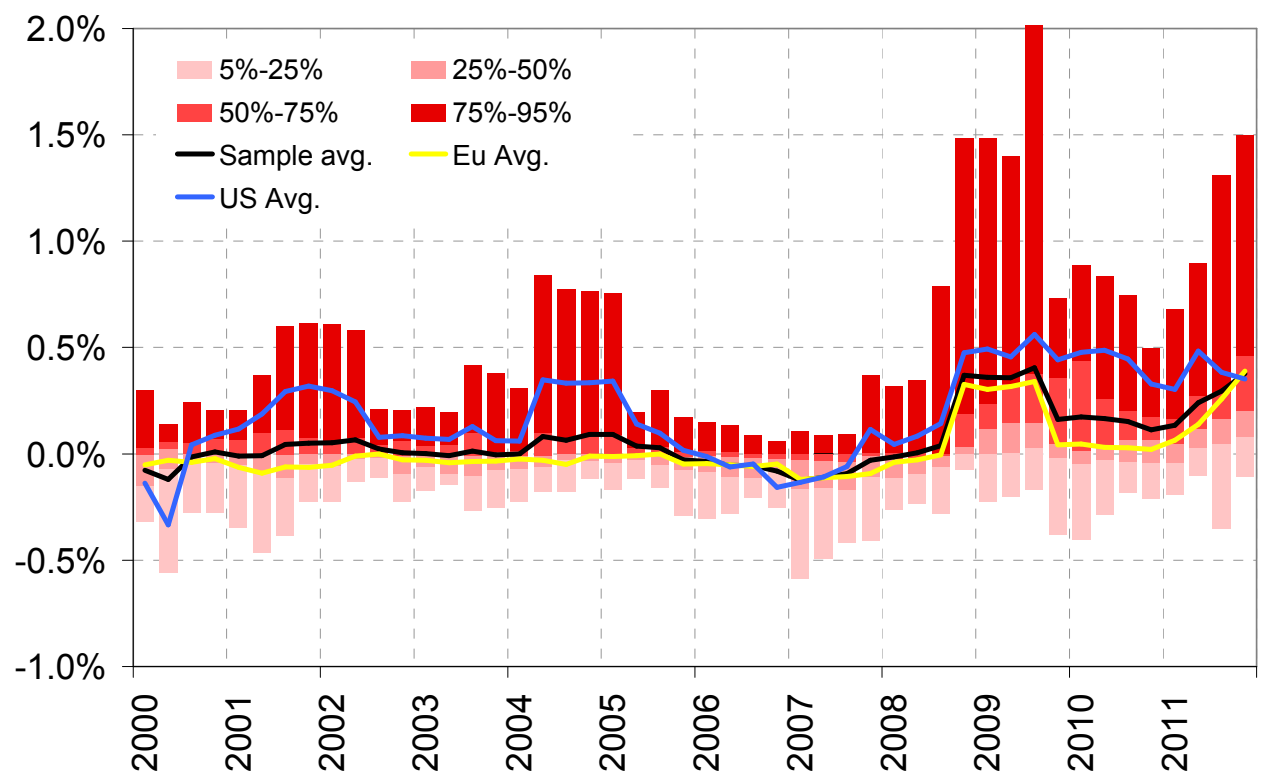

Source: Authors' calculations on Bloomberg data

Note: Values are calculated as the ratio between extraordinary items to total assets for each bank, then, mean values are calculated with the singlebank ratio data. The percentile range distribution is also calculated on single-bank ratio data. Quarterly data (annualized via the trailing sum of the last 4 quarters for every observation). To enhance the insight of the graph, the scale of the y-axis has been restricted, even if it cuts off some relevant values of the figures.

\footnotetext{
${ }^{8}$ As can be seen from Chart 9, these items may eventually account for extraordinary gains.
} 
In the end, the recovery of banking profitability experienced after the crisis - see Chart 5 has been weak and sluggish, as a consequence of unresolved fragilities in balance sheets (in particular the need for deleveraging and getting rid of toxic assets, scaling back the most risky activities, anaemic economic growth). The average ROE for North-American banks stabilized below historical level, just below $10 \%{ }^{9}$. However European banks, having been severely affected by the Sovereign Debt crisis showed a declining profitability from the beginning of 2011, with any positive profitability almost wiped out at the end of 2011. The main causes for this sharp decline are to be found in the market tensions connected with the Sovereign Debt Crisis, the higher costs of wholesale funding and write-downs for reduced value of Eurozone sovereign bonds holdings. Notably the write-downs on Greek sovereign bonds holdings led Dexia to a de-facto bankruptcy between 2011:Q3 and Q4 and to the projected split of its activities. While the GFC affected firstly American banks and then expanded worldwide, the sovereign debt crisis looks mainly as a European affair. The increased dispersion at the end of 2011 is mainly due to the steep drop in profitability for Italian and French banks and Dexia. Given the gloomy forecasts for economic growth in Europe (especially in Southern European countries), the still unresolved sovereign debt crisis - with its negative effect on banks funding conditions (Panetta et al. (2011)) - and the deleveraging still under way, prospects for European banks' profitability appear grim.

\section{The Response to the Crisis: The return to Traditional Banking?}

The disruption caused by the global financial crisis was so deep and so widespread that completely changed the banking industry landscape, besides the reduced profitability. Some changes can be interpreted as an endogenous response by the banking sector to a more challenging and risky financial environment, while other changes are driven by the effort of regulatory authorities to plug the gaps emerged during the crisis. The main shifts can be identified in three areas: capital ratios, liquidity and non-interest banking activity.

The main lasting legacy from the Global Financial Crisis, which is meant to be one of the main bulwarks against the arising of a new crisis is higher capital ratios. In fact, most of the banks of the sample entered the crisis undercapitalized and overleveraged (say nothing of the weaker banks that went underwater during the crisis). Moreover, as Panetta et al (2009b) clearly point out, several governments needed to provide capital injections of unprecedented measures to strengthen capital bases. Thus the bulk of regulatory efforts concentrated on improving the capital requirements for banks through an increase in the quantity of capital and in its quality. The

\footnotetext{
${ }^{9}$ Even though some banks, like Bank of America, are still struggling to earn a positive stream of income.
} 
backbone of the new global regulatory framework - commonly known as Basel $\mathrm{III}^{10}-$ deals with the improvement of banking capital bases.

This effort can be clearly seen from Chart 10, where the average and distribution of Tier 1 Capital Ratio is plotted. Since 2008 the Tier 1 Capital Ratio has increased by about 50\%, breaching an average level of $12 \%$. Moreover some national regulatory authorities are asking for even higher capital requirements (e.g. Switzerland and the UK, in fact banks headquartered in these two countries have higher capital ratios, averaging 14\%). The North-American average is still higher because in this subgroup there is a greater share of investment banks which have stronger capital positions. The 10 less capitalized banks of the sample at the end of 2011 are all from Eurozone countries. However, they are expected to improve their capital positions, also as a result of the EBA recommendation on capital requirements ${ }^{11}$. These improvements in capital bases were the main driver of deleveraging, together with a sudden stop in assets growth, as briefly shown in Section 3.

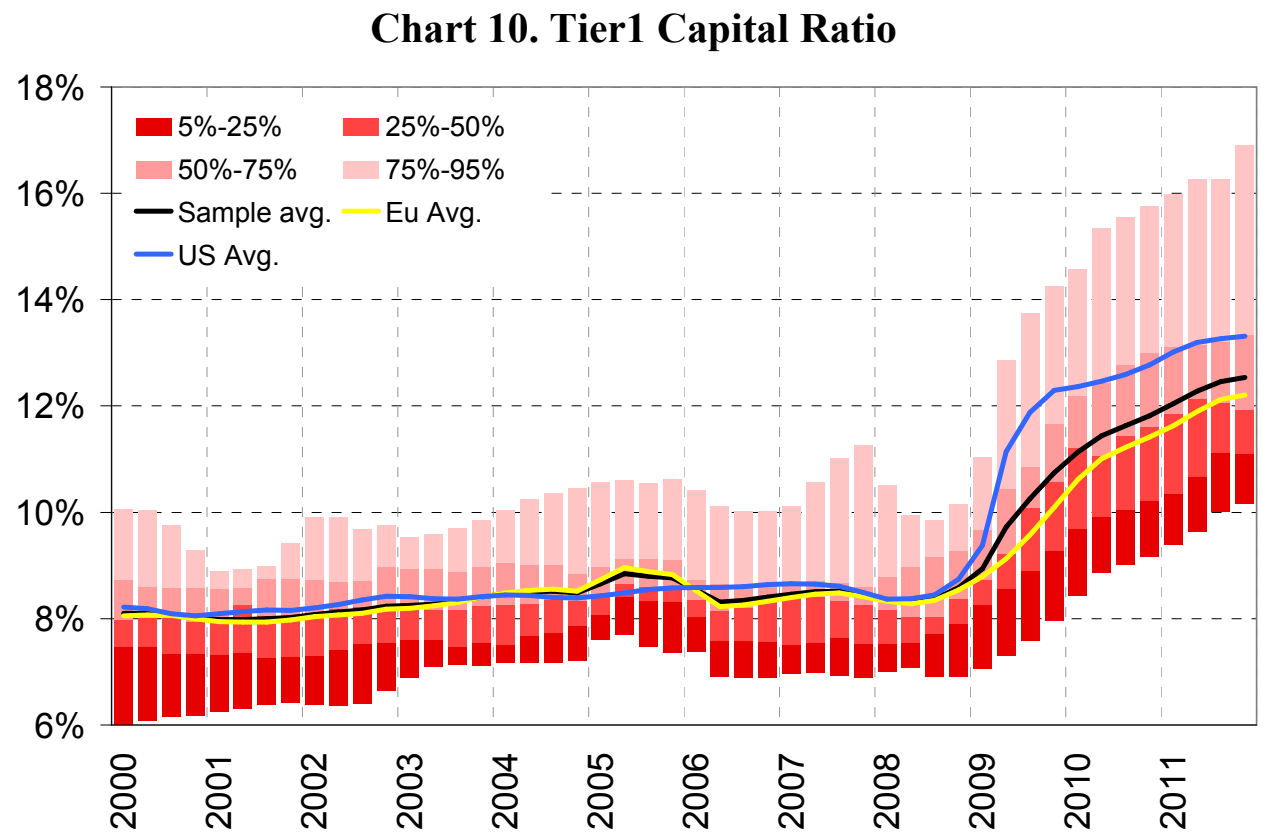

Source: Authors' calculations on Bloomberg data

Note: Mean values and the percentile range distribution are calculated aggregating Tier 1 Capital Ratios data for each bank. Quarterly data (annualized via the trailing sum of the last 4 quarters for every observation).

A possible drawback is that the tighter regulation and the increase in capital positions can lead to a lower average profitability in the future. There might also be the scope for an enhanced role of the shadow banking system. Moreover, as in Adrian and Shin (2010b), the protracted

\footnotetext{
${ }^{10}$ For further details on the rationale and features of the new capital regulation, see: "Basel III: A global regulatory framework for more resilient banks and banking systems", BIS, BCBS - June 2011.

${ }^{11}$ For further details on the recommendation see "EBA Recommendation on the creation and supervisory oversight of temporary capital buffers to restore market confidence", EBA/REC/2011/1.
} 
negative relation between increases in capital base and leverage could further depress asset prices, with negative second-round spillovers to banks balance sheets and the risk of a major contraction in lending if not a credit crunch.

The second relevant feature pertains to liquidity. On the verge of the crisis, central banks responded to the freeze of the interbank market pushing short-term interest rates to their zero bound. Then they resorted to massive liquidity injections to counter the drying up of banking liquidity and supplant banks deleveraging (Adrian and Shin (2010a)).

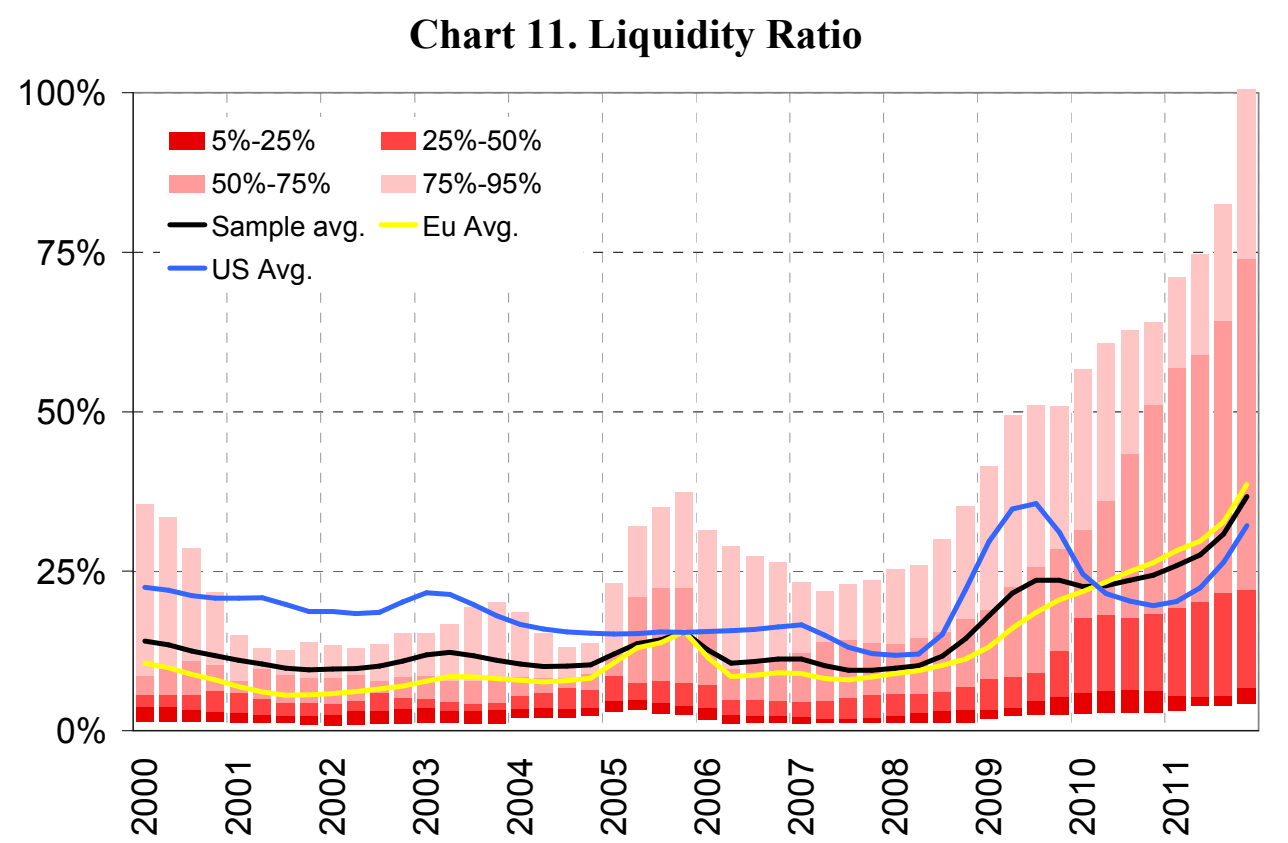

Source: Authors' calculations on Bloomberg data

Note: Values are calculated as the ratio between cash and near-cash items to short term borrowing for each bank, then, mean values are calculated with the single-bank ratio data. The percentile range distribution is also calculated on single-bank ratio data. Quarterly data (annualized via the trailing sum of the last 4 quarters for every observation). To enhance the insight of the graph, the scale of the y-axis has been restricted, even if it cuts off some relevant values of the figures.

The flooding of the financial system with liquidity has been connected with the massive surge of spare liquidity holdings on banks' balance sheets. Chart 11 shows the Liquidity Ratio calculated as the ratio between cash and near cash items to short-term borrowings. This ratio, fairly stable between 2000 and 2008 for European banks and showing a downward trend for their American peers ${ }^{12}$, started to increase in 2008:Q3 - notably the quarter in which Lehman Brothers collapsed - reaching the all-time high value of $30 \%$ at the end of the series. This upward trend in the liquidity ratio can be mainly explained by demand factors. In fact, the breakdown in the interbank money market and the higher levels of volatility and risk aversion experienced in financial markets from 2007 might have pushed banks to hoard more liquidity than ever. The

\footnotetext{
12 The higher average level for North-American banks, during the pre-crisis years, is caused by the high values reported by Bank of New York Mellon, which always held large amount of free liquidity.
} 
massive provisions of cheap liquidity to the banking system by monetary authorities allowed banks to quickly substitute inter-bank funding with official funding. Interestingly, the bell in the average for the North-American subsample coincided with the maximum amount of liquidity provided by the Federal Reserve, while, the upward trending path in the European subsample is consistent with the increase in liquidity provisions by the ECB.

However the sample is deeply heterogeneous: most of French, Italian and Spanish banks maintained a liquidity ratio broadly in line with its pre-crisis level, while some other banks (like English and Swiss banks) accounted for most of the increases. Another cause behind this surge in liquidity ratio may be identified in regulatory changes, aimed at reducing the likelihood of new liquidity shortages in the future. While the tougher stance undertaken by Swiss and British authorities in upgrading the supervisory requirements is at the root of the impressive increase in the liquidity ratio for their banks, it must not be forgotten that the new Basel III accord provide for a new Liquidity Coverage Ratio and a Net Stable Funding Ratio to be complied with ${ }^{13}$. Although this new liquidity monitoring framework will start to be introduced only from 2015 onwards, some banks could already be adapting their balance sheets structures to the new standards.

The third relevant aspect is connected with non-interest banking activity, encompassing all the riskier and more profitable activities - mainly trading - that caused the huge losses during the crisis, as shown in Section 4. While several measures have been undertaken within the Basel framework (e.g. increasing the risk weights of several types of securities holdings), its paradigm has not changed and the universal banking model is not under revision. However, some jurisdictions are evaluating harsher measures, which would definitely twist the future banking landscape. In the US, the much disputed "Volcker Rule", contained in the Dodd-Frank reform bill, could come into full effect by 2012. It proposes a ban on proprietary trading by banks that take retail deposits and prevents them from owning hedge funds. Moreover, in the UK, the Independent Commission on Banking (ICB) ${ }^{14}$ published its final report in late 2011, proposing the ring-fencing of retail banking operations of UK banks from their riskier investment banking operations and a further strengthening of capital bases by 2019. In the same light, the OECD (2009) proposed the legal separation between investment and retail banking activities, through the creation of a NonOperating Holding Company (NOHC) that would invest, as a parent, in its operating affiliates.

These measures have the aim of preserving financial stability through the separation of retail banking from riskier activities, thus going in the opposite direction of the deregulation of the

\footnotetext{
${ }^{13}$ For further details on the rationale and features of these ratios, see: "Basel III: International framework for liquidity risk measurement, standards and monitoring", BIS, BCBS - December 2010.

${ }^{14}$ The ICB was created in 2010 by the UK Chancellor of the Exchequer, in order to evaluate possible reforms to the UK banking sector to promote financial stability and competition, and to make recommendations to the Government.
} 
banking sector occurred from the 1990s. In the words of De Grauwe (2009), these measures would signal the end of the universal banking model, and the return of some kind of narrower banking (because activities bank can engage in are narrowly defined). However, to make these measures fully effective - and to rule the end of universal banking - they should be adopted globally. Instead, the new Basel III framework does not ban banks from engaging in investment banking activities, even if provides a set of new, tighter rules, with the aim of lessening the risks that weigh on retail banking. Given the potentials of financial innovation and regulatory arbitrage, this might well be enough to allow banks to continue their business as usual, failing to substantially decrease banks' exposure to financial risks.

\section{Empirical Analysis}

As seen in the previous section, regulatory changes in capital ratios, liquidity holdings and noninterest activity are expected to deeply affect the prevailing banking model. Their declared aim is to reduce banks' riskiness and exposure to financial disruptions. But this objective might lead to a permanently diminished average profitability. As a consequence the way the banking business will be run in the future might swiftly change. Therefore their potential should be evaluated with care in order to avoid undesired effects on the industry.

This section tries to assess - through a set of panel regressions - the relative effectiveness of these measures and their potential effects on banking profitability and riskiness. In fact, since most of these measures are already under implementation and their effects are unfolding, it is possible to investigate the topic. Moreover this large sample of global banks offers a unique view of the changes currently under way in the banking industry and what can be expected for the future of universal banking.

Moreover, it is worth considering the potential multiplier effect that can arise from these measures being simultaneously undertaken by most of the banks of the sample at the same time. The interconnectedness between these banks and their major share of the overall banking business in Europe and North America can well magnify the effects of the regulatory changes, with relevant implications for the banking industry and financial stability.

Two sets of regressions are shown, where two different dependent variables accounts for profitability and riskiness. We chose ROE as the profitability variable. The choice for a riskiness variable has been less straightforward: we selected the volatility of ROE over four quarters (that is, over a year) as the most proper one. Several alternative choices were available among market variables, like Price-to-Book values and Credit Default Swaps, however we limited our analysis to 
financial statements data. In this way results of the two sets of regressors could be more properly compared. Finally, being ROE the ratio of net income to total common equity, its numerator is affected by any type of loss and impairment, thus its volatility is a good measure of the overall riskiness of the banking industry. The regression equation has the following functional form:

$$
y_{i, t}=\alpha+\beta y_{i, t-1}+\gamma_{1} X_{i, t}+\gamma_{2} X_{t}^{*}+\boldsymbol{v}_{i}+\boldsymbol{\varepsilon}_{i, t}
$$

In this equation, $y_{i, t-1}$ is the lagged dependent variable (either ROE or ROE volatility). We chose to add dynamics in the model specification. The relation can be considered dynamic in nature as a bank's profitability or riskiness profile may adapt only gradually to new conditions and with consistent lags, due to the complexity of reshaping its business model. Moreover banks can choose to anticipate or delay certain one-off measures in order to smooth their profitability across quarters and reach some pre-determined targets. $X_{i, t}$ and $X_{t}^{*}$ are matrices made of the set of variables that are experiencing major regulatory changes in recent year: liquidity ratio; Tier 1 capital ratio; share of non-interest activity ${ }^{15}$. The former matrix is filled with data at single-bank level, while the latter is filled with the sample averages. In this way we try to capture the effect of the changes unfolding in the whole banking system on a single bank's profitability and riskiness. Single-bank changes and system-wide changes might then be self-reinforcing.

As previously stated, our sample encompasses the 27 banks listed in Table 1. Our time-span is 1999:Q4 - 2011:Q4, totalling 48 quarters. The panel is almost perfectly balanced, having only few variables with missing values ${ }^{16}$. Given the dynamic relation specified in the regression equation, the models are estimated with the Arellano and Bond (1991) GMM estimator.

We run the regressions on two different time samples for both the dependent variables: the whole sample (henceforth "Sample A") and the post-crisis sample (2009:Q1 - 2011:Q4), which totals 12 quarters (henceforth "Sample B"). The rationale for this choice is that two regressors (liquidity ratio and Tier 1 capital ratio) incurred a structural break, given the first regulatory changes were enforced after the Lehman Brothers bankruptcy, while before this event these variables showed almost no variability. Thus, for these two variables we consider more reliable the results arising from Sample B. At the same time, non-interest activity, while shrinking in the post-crisis sample, had been on the rise in the previous years. We run the same set of model specifications for both the dependent variables, in order to state more clearly how the regressors

\footnotetext{
${ }^{15}$ The definitions of variables used in the regressions are the same as those shown in the previous pages.

${ }^{16}$ Tier 1 Capital ratio was not disclosed by Goldman Sachs and Morgan Stanley until 2009:Q1. By that date the two securities firms became traditional bank holding companies, regulated by the FED, to get easier access to official funding.
} 
contemporaneously affect risk and profitability. Then relevant insights can be inferred from both time-samples. The regressions results are shown in Table 3.

In equations (1)-(2), ROE is regressed against single banks' relevant variables only, leaving aside the system-wide set of regressors. In agreement with intuition, profitability appears to be negatively affected by an increase in liquidity holdings (significant negative sign) and by a decrease in the share of non-interest activity (significant positive sign). Their coefficients appear similar in magnitude. However, Tier 1 capital ratio shows a significant positive coefficient, with a far higher magnitude, leading to the counterintuitive interpretation that an increase in the capital base would strongly support an increase in profitability.

Equations (5)-(6) show the same model specification when ROE volatility is the dependent variable. Coefficients for liquidity and non-interest activity are not statistically significant or negligible in magnitude. Tier 1 capital ratio's coefficient is instead negative and significant showing that its increase would reduce a bank's riskiness.

Summing up, the comparative analysis of the measures currently under way shows that increasing the Tier 1 capital ratio would be a panacea for banks, leading to a contemporaneous increase in profitability and decrease in riskiness. Conversely, increasing the holdings of liquid assets or decreasing the share of non-interest based activity would lower a bank's profitability without having a significant effect in lowering its riskiness. Therefore, according to these preliminary results, banks should only increase their capital base, rather than increase their liquid holdings or be forced to reduce their investment banking activities, which would not improve their risk position. This set of results might well change once the sector overhaul is taken into consideration. In fact, the shared effort of the banking sector towards the new regulatory requirements could have a relevant spill-over impact on banking profitability and riskiness. Thus including the system-wide average variables would present a more accurate picture.

When these variables are included in the model specification, results change in a relevant manner. Equations (3)-(4) detect the effect of bank-specific and system-wide measures on profitability. Eq. (3), based on the entire time-sample, provides evidences only for a positive relation between the share of non-interest activity (both at bank and system level) and ROE. Eq. (4) confirms this positive relation, with a much stronger magnitude for the system-wide variable and adds a negative relation between the system-wide liquidity and the ROE. Thus, while a single bank's higher liquidity ratio appears not to constrain its profitability, an increase in the average liquidity holding of the banking system appears to do so. Since the liquidity ratio we are considering is calculated as the ratio of cash and near cash items to short term debt, its increase can depend on both components. The effort by many banks to increase the former component of 
the ratio or decrease the latter (with a combined effort to increase the stable source of funding) at the same time, might create pressures on prices, making both the liquid assets and the stable sources of funding more expensive. These dynamics, together with an overall reduction in credit growth to the broader economy, can be detrimental of profitability at a systemic level. This interpretation is quite in line with the prevailing view of the financial services industry (see, for instance, EBA's Banking Stakeholder Group (2012) or IIF (2011)). Eq. (4) also shows that there's no statistically significant relation between the Tier 1 capital ratio and profitability, both at the system and single bank's level. Moreover it confirms the positive relation of eq. (3) between ROE and the share of non-interest activity. A decrease in such activity would hamper profitability. The coefficient for the system-wide non-interest activity is far higher that the single bank's coefficient. This result might be caused by a considerable self-reinforcing trend within the industry, but might account for a spurious effect due to an average-smoothing effect of the variable.

Both the Sargan Test for overidentifying restrictions and the Arellano-Bond Test for first and second order autocorrelation in the first-differenced errors confirm that the equations above are well specified.

Among the other variables that could have proved relevant for profitability, quite surprisingly leverage did not show any degree of statistical significance in none of the sample and with any specification (levels, first differences, lagged levels, sample-averages). As a robustness check some regressions with alternative dependent variables - like ROA, OROA and Income-toCost Ratio - were run ${ }^{17}$. The results of Table 3 are broadly confirmed, with respect to statistical significance and magnitude of the coefficients.

The same models specifications as above were run for subsamples of banks (according to their prevailing business model, as in Table 2, and geographical location). The inverse relation between ROE and system-wide liquidity is confirmed and strengthen its magnitude for universal and investment banks. The same is true for the non-interest activity ratio. These relations appear weakest for retail banks. Accordingly, Eurozone banks, where a higher share of retail banks is located, show somewhat weaker relations too.

\footnotetext{
${ }^{17} \mathrm{ROA}$ is calculated as the ratio between net income and total assets, following the procedure explained in the footnote of Chart 5. Analogously OROA is calculated as the ratio between operating income and total assets. The calculation of Income-to-Cost Ratio is described in the footnote of Chart 3, lhs.
} 
Table 3. Panel Regressions

\begin{tabular}{|c|c|c|c|c|c|c|c|c|}
\hline & \multicolumn{4}{|c|}{ Dep. Var. ROE } & \multicolumn{4}{|c|}{ Dep. Var. ROE Volatility } \\
\hline & (1) & (2) & (3) & (4) & $(5)$ & $(6)$ & (7) & (8) \\
\hline & GMM & GMM & GMM & GMM & GMM & GMM & GMM & GMM \\
\hline time-sample & A & $\mathrm{B}$ & $\mathrm{A}$ & B & A & $\mathrm{B}$ & A & $\mathrm{B}$ \\
\hline Dep. Variable (t-1) & $\begin{array}{c}0.875 \\
(74.16)^{* *}\end{array}$ & $\begin{array}{c}0.690 \\
(23.57)^{* *}\end{array}$ & $\begin{array}{c}0.849 \\
(67.22)^{* *}\end{array}$ & $\begin{array}{c}0.694 \\
(22.76)^{* *}\end{array}$ & $\begin{array}{c}0.743 \\
(39.81)^{* *}\end{array}$ & $\begin{array}{c}0.523 \\
(12.72)^{* *}\end{array}$ & $\begin{array}{c}0.729 \\
(21.76)^{* *}\end{array}$ & $\begin{array}{c}0.516 \\
(12.30)^{* *}\end{array}$ \\
\hline Liquidity & $\begin{array}{l}0.004 \\
(0.36)\end{array}$ & $\begin{array}{c}-0.042 \\
(-1.80)^{*}\end{array}$ & $\begin{array}{l}0.008 \\
(0.72)\end{array}$ & $\begin{array}{l}-0.020 \\
(-0.83)\end{array}$ & $\begin{array}{c}-0.0001 \\
(0.03)\end{array}$ & $\begin{array}{l}-0.001 \\
-0.12)\end{array}$ & $\begin{array}{l}-0.002 \\
-0.38)\end{array}$ & $\begin{array}{l}-0.003 \\
(-0.26)\end{array}$ \\
\hline Overall Liquidity & & & $\begin{array}{l}0.096 \\
(1.37)\end{array}$ & $\begin{array}{l}-0.201 \\
(-1.66)^{*}\end{array}$ & & & $\begin{array}{c}0.061 \\
(1.70)^{*}\end{array}$ & $\begin{array}{l}0.063 \\
(1.07)\end{array}$ \\
\hline Tier 1 & $\begin{array}{l}-0.034 \\
(-0.30)\end{array}$ & $\begin{array}{c}1.028 \\
(3.73)^{* *}\end{array}$ & $\begin{array}{l}-0.083 \\
(-0.38)\end{array}$ & $\begin{array}{l}0.189 \\
(0.34)\end{array}$ & $\begin{array}{c}-0.105 \\
(-1.90)^{*}\end{array}$ & $\begin{array}{c}-0.629 \\
(-4.73)^{* *}\end{array}$ & $\begin{array}{l}-0.180 \\
(-1.57)\end{array}$ & $\begin{array}{c}-0.568 \\
(-2.09)^{* *}\end{array}$ \\
\hline Overall Tier 1 & & & $\begin{array}{l}-0.223 \\
(-0.60)\end{array}$ & $\begin{array}{l}0.991 \\
(1.28)\end{array}$ & & & $\begin{array}{l}-0.207 \\
(-1.06)\end{array}$ & $\begin{array}{l}-0.524 \\
(-1.08)\end{array}$ \\
\hline N-I Activity & $\begin{array}{c}0.040 \\
(5.18)^{* *}\end{array}$ & $\begin{array}{c}0.059 \\
(4.56)^{* *}\end{array}$ & $\begin{array}{c}0.021 \\
(2.60)^{* *}\end{array}$ & $\begin{array}{c}0.047 \\
(3.49)^{* *}\end{array}$ & $\begin{array}{c}-0.009 \\
(-2.39)^{* *}\end{array}$ & $\begin{array}{l}-0.005 \\
(-0.70)\end{array}$ & $\begin{array}{l}-0.004 \\
(-0.92)\end{array}$ & $\begin{array}{c}0.070 \\
(2.15)^{* *}\end{array}$ \\
\hline Overall N-I Activity & & & $\begin{array}{c}0.173 \\
(6.71)^{* *}\end{array}$ & $\begin{array}{c}0.187 \\
(2.87)^{* *}\end{array}$ & & & $\begin{array}{c}-0.025 \\
(-2.05)^{* *}\end{array}$ & $\begin{array}{c}0.096 \\
(5.81)^{* *}\end{array}$ \\
\hline Wald & 6309 & 850 & 6531 & 863 & 1650 & 279 & 1675 & 283 \\
\hline N. of obs. & 1173 & 320 & 1173 & 320 & 1104 & 320 & 1104 & 320 \\
\hline
\end{tabular}

Notes: for every variable two values are shown, its coefficient and below its t-statistics (between parentheses).

The symbol $(*)$ is for statistical significance of $10 \%$, while $(* *)$ is for statistical significance of $5 \%$. 
Summing up, banks' profitability is likely to be negatively influenced by the measures aimed at increasing the ratio of spare liquidity on a systemic level, while a single bank's liquidity provision would not hamper its profitability. Decreasing the share of non-interest activity would likely decrease profitability, both at single-bank and system-wide level. Quite surprisingly, the improvement in capital ratios (namely, the Tier 1 ratio) does not seem to negatively affect profitability. The impact of these measures provides its maximum magnitude for universal and investment banks.

The riskiness analysis, shown in eq. (7)-(8), provides similarly interesting results. The complete time sample estimation (eq. (7)), provides a weakly significantly positive coefficient for the system-wide liquidity and a significantly negative coefficient for the system-wide share of non-interest activity. These results are in stark contrast with the economic evidence, as an increase in the liquidity ratio or a reduction in the share of non-interest activity would lead to an increase of ROE volatility. However, equation (8), restricted on the post-crisis subsample, provides more reliable results. Liquidity ratios do not appear to affect banks' riskiness. The Tier 1 capital ratio has instead a significant negative relation with ROE volatility. Thus its increase would lead to a reduction in a bank's riskiness. Interestingly enough, the system-wide Tier 1 variable is not statistically significant, rejecting the potential systemic effect of increasing the average capital base of the industry. Analogously to profitability, the share of non-interest activity has a significant positive relation with ROE volatility both at the single and systemic level. A decrease in the share of non-interest activity would then lead to a decrease in banking riskiness ${ }^{18}$.

According to the previous analysis of profitability, leverage does not show any statistical significance. Moreover ROE volatility is not explained by measures of risk aversion (like the ViX Index) or fluctuations in stock and bond markets. As a robustness check we used some slightly different definitions of banks' riskiness (like negative ROE, strong variation of $\mathrm{ROE}^{19}$ ). However, given the large difference of these alternative variables definitions with respect to ROE volatility, the results of Table 3 appear somewhat less stable than those calculated for profitability. As in the profitability case, the significance and magnitude of the coefficients are higher for universal and investment banks.

Summing up, the comparative analysis of the measures currently under way to improve the resilience of the banking sector shows that increasing the holdings of liquid assets can lower

\footnotetext{
${ }^{18}$ As in the previous set of regressions, both the Sargan and the Arellano-Bond Tests were performed confirming the good specification of the equations.

${ }^{19}$ Strong variation of ROE is calculated as a variation of ROE higher than $50 \%$ qoq, zero otherwise.
} 
banking profitability without having a significant effect on riskiness. This effect would mainly arise through the systemic channel. Conversely, the regressions show that an increase in Tier 1 capital ratio could significantly decrease a bank's riskiness, but there's no evidence that this increase would respectively lower its profitability. This effect would be mainly confined to the single-bank level. Decreasing the share of non-interest activities could reduce profitability and riskiness at the same time. This reduction might arise both from single-bank and system-wide decreases in the ratios. Measures aimed at containing leverage do not appear to play a significant role in changing the riskiness-profitability profile of the banks of the sample.

Therefore, according to the results shown in Table 3, a bank that increases its liquidity and Tier 1 capital ratios and decreases its share of non-interest activity would witness a direct effect on riskiness (by increasing Tier 1 and decreasing N-I activity) and on profitability (by decreasing N-I activity). However, these regulatory changes, while sometimes not directly influential at the single-bank level, have a relevant indirect effect, once we consider the whole banking system's changing environment in the analysis. In this light, while the Tier 1 ratio does not appear to be very influential on a system-wide basis, the liquidity ratio shows a contractionary effect on profitability. The indirect effect of decreasing the share of non-interest activity is mutually reinforcing with the direct effect highlighted above.

All in all, from a riskiness-profitability perspective at the single bank level, a financial institution should primarily head its efforts towards a strengthening of capital adequacy ratios, then towards a restriction of the share of non-interest activities. Increasing the holdings of liquid assets does not seem to have a positive effect in term of improving the risk-profitability balance. These measures seem more likely to affect the business model of universal and investment banks, leaving retail banks less affected by these changes. Up to the end of 2011, these measures had already concurred to somewhat decrease the profitability and the riskiness of banks. In this light, the data up to the end of 2011 confirm that banks are actually heading for a safer and narrower business model.

These conclusions might well change once the objective switch from single bank profitability to the financial stability of the overall financial system. While our simple model can capture the systemic effects of the regulatory changes under way on single bank profitability, it does not answer the question of what contribution any bank brings to financial stability by improving its liquidity, capital and risk positions. It does not show either how the broader economy is likely to be affected by these changes, even if the decrease of profitability might signal a cost for the broader economy. However, as some studies provide very different results - e.g. IIF (2011), IMF (2012), etc. - the estimation of this cost is very controversial. 
Moreover, this analysis could yield to different conclusions once the sample of banks is broadened and the post-crisis time sample is lengthened, and once potential interaction effects between these measures and other business choices are taken into account. In fact, being the banking sector overhaul only at its beginning, it is possible that banks will dynamically adapt their strategies through time to the new financial and regulatory landscape.

\section{Concluding Remarks}

This note analyzes the main changes occurred to the largest banks, since the late nineties, through the analysis of their balance sheets. Favoured by banking sector deregulation and buoyant financial innovation, changes were massive, both in the run-up and in the aftermath of the global financial crisis started in 2007. Those changes, especially in the boom years, can be summarized as the rise of the universal bank model. Until 2007, banks showed ever-increasing profitability, due to a relevant degree to investment banking activities. These changes were sharpest for the European banks of the sample, traditionally more retail-oriented.

The growing profitability obscured many weaknesses of the banking system, which became self-evident only with the eruption of the crisis. Banks were overleveraged and, favoured by a low-interest and low-volatility environment, embarked in excessive risk-taking.

The eruption of the crisis, in 2007, triggered a sharp reversal in all relevant indicators. Huge losses in trading and lending portfolios, write-downs of assets holdings caused a sharp drop of profitability to its minimum value throughout the decade in 2008-2009. The recovery observed in financial markets from the second quarter of 2009 provided only a partial relief.

In fact profitability, with banks committed to a painful deleveraging (through the strengthening of the capital base or the shedding of assets), stabilized beneath its pre-crisis level. European banks had been slower in adapting to the new financial and regulatory landscape. Given the grim economic performance of the European economy, connected with the arising of the sovereign debt crisis in the Eurozone, European banks suffered new trading losses and a share of non-performing assets still on the rise. Not surprisingly profitability narrowed sharply again. Considering the higher fragility of the European funding model, European banks are in a much worse position than their North-American peers.

The regulatory developments undertaken by national and supranational authorities in order to repair a broken financial system and to improve banks' resilience range from tougher capital requirements to new sets of rules regarding improved liquidity and leverage positions. The current debate aims at a reduced role for wholesale and investment banking activity. Despite many 
improvements are under way, increasing the capital position and profitability at the same time is proving to be a formidable challenge, especially for many banks from the Eurozone. Moreover, exerting these efforts in a time of weak economic recovery and still higher-than-normal risk aversion makes the achievement even harder.

The econometric evidence suggests these measures are already unfolding their effects on banking business model. Taken together, they are decreasing the riskiness and profitability embedded in the banking activity. While a decrease of the former is a desired outcome, a decrease of the latter should be avoided as much as it is possible, as it might create the scope for regulatory arbitrage and for an enhanced role of the shadow banking system. In this light, further evidence shows that the system-wide effect of these measures being contemporaneously undertaken by several banks is significant in strengthening their impact on banking riskiness and profitability. The best measure seems to be increasing the Tier 1 capital ratio, while the least preferable measure would be increasing the liquidity ratio. Since the effect of these new requirements are only recently starting to being felt, banks might well adapt their business models in order to offset the negative effects on profitability, providing further scope for investigation on the topic. However, a safer banking sector might not be consistent with pre-crisis profitability levels. Thus these changes might well challenge the universal banking business model as such.

Moreover, policy choices currently debated in the US and UK might definitely lead the way to a different, safer, banking model, based on the traditional deposit taking and lending activities, and separated from the investment banking activities. But the pace of financial innovation, the growing role of the shadow banking system, and the deep interconnectedness between financial institutions suggest that the path to some kind of more traditional banking might be hard as well. 


\section{References}

Adrian, Tobias and Hyun Song Shin, (2010a), "The Changing Nature of Financial Intermediation and the Financial Crisis of 2007-2009", Federal Reserve of New York Staff Report No. 439, April 2010

Adrian, Tobias and Hyun Song Shin, (2010b), "Liquidity and Leverage", Journal of Financial Intermediation, Vol. 19 Issue 3, July 2010

Adrian, Tobias and Hyun Song Shin, (2011), "Financial Intermediary Balance Sheet Management", Federal Reserve Bank of New York Staff Reports, No. 532

Agarwal, Sumit, Gene Amromin, Itzhak Ben-David, Souphala Chomsisengphet and Douglas D. Evanoff, (2011), "The Role of Securitization in Mortgage Renegotiation", Journal of Financial Economics, Volume 102, Issue 3, December 2011

Arellano, Manuel and Stephen Bond, (1991), "Some Tests of Specification for Panel Data: Monte Carlo Evidence and an Application to Employment Equations", Review of Economic Studies 58: 277-297.

Bank for International Settlements (BIS), (2012), "Guideline to the International Consolidated Banking Statistics”, Bank for International Settlements, February 2012

Barth, James, Dan Brumbaugh Jr. and James Wilcox, (2000), "The Repeal of Glass-Steagall and the Advent of Broad Banking", Journal of Economic Perspectives, Vol.14 No.2, Spring 2000

Basel Committee on Banking Supervision, (2010), "Basel III: International framework for liquidity risk measurement, standards and monitoring", Bank for International Settlements, December 2010

Basel Committee on Banking Supervision, (2011), "Basel III: A global regulatory framework for more resilient banks and banking systems", Bank for International Settlements, June 2011

Benink, Harald and George Benston, (2005), "The Future of Banking Regulation in Developed Countries: Lessons from and for Europe”, Financial Markets, Institutions and Instruments, Vol 14 Issue 5, December 2005

Bordo, Michael, (2008), "An Historical Perspective on the Crisis of 2007-2008", NBER Working Paper No. 14569, December 2008

Borio, Claudio, (2010), “Ten Propositions about Liquidity Crises”, CESifo Economic Studies, Vol. $561 / 2010$

Brunnermeier, Markus, (2008), "Deciphering the 2007-08 Liquidity Crisis and Credit Crunch", NBER Working Paper No. 14612, December 2008

Davies, Richard, Peter Richardson, Vaiva Katinaite and Mark Manning, (2010), "Evolution of the UK Banking System", Bank of England Quarterly Bulletin 2010 Q4 
De Grauwe, Paul, (2008), “The banking crisis: causes, consequences and remedies", CEPS Policy Brief No. 178, November 2008

De Grauwe, Paul, (2009), "Lessons from the banking crisis, a return to narrow banking", CESifo DICE Report Vol,7 Issue 2, 2009

EBA’s Banking Stakeholder Group, (2012), "New Bank Liquidity Rules: Dangers Ahead”, Position Paper

Elsas, Ralf, Andreas Hackethal and Markus Holzhäuser, (2010), "The Anatomy of Bank Diversification”, Journal of Banking \& Finance, Vol. 34 Issue 6, June 2010

European Banking Authority (EBA), (2011), "EBA Recommendation on the creation and supervisory oversight of temporary capital buffers to restore market confidence", EBA/REC/2011/1

Financial Stability Board (FSB), (2011), "Policy measures to address systemically important financial institutions (SIFIs)", FSB, November 2011

Goldberg, Linda, (2009), "Understanding Banking Sector Globalization”, IMF Staff Papers, Vol. 56 No. 1, 2009

Group of Ten, (2001), "Report on consolidation in the financial sector", Bank for International Settlements.

Institute of International Finance (IIF), (2011), "The Cumulative Impact on the Global Economy of Changes in the Financial Regulatory Framework", IIF, Washington, US, September 2011

International Monetary Fund (IMF), (2012), "Estimating the Costs of Financial Regulation", prepared by André Oliveira Santos and Douglas Elliot, IMF Staff Discussion Note, September 2012, SDN/12/11

OECD, (2009), “The Financial Crisis: Reform and Exit Strategies”, OECD, Paris

Ongena, Steven and José-Luis Peydrò, (2011), "Loose monetary policy and excessive credit and liquidity risk-taking by banks", in "The Future of Banking”, edited by Thorsten Beck

Panetta, Fabio, Paolo Angelini, Ugo Albertazzi, Francesco Columba, Wanda Cornacchia, Antonio Di Cesare, Andrea Pilati, Carmelo Salleo and Giovanni Santini, (2009a), "Financial Sector Pro-cyclicality: Lessons from the Crisis", Bank of Italy Occasional Paper No. 44, April 2009

Panetta, Fabio, Thomas Faeh, Giuseppe Grande, Corinne Ho, Michael King, Aviram Levy, Federico Signoretti, Marco Taboga and Andrea Zaghini, (2009b), "An Assessment of Financial Sector Rescue Programmes”, Bank of Italy Occasional Paper No. 47, July 2009

Panetta, Fabio, Ricardo Correa, Michael Davies, Antonio Di Cesare, José-Manuel Marques, Francisco Nadal de Simone, Federico Signoretti, Cristina Vespro, Siret Vildo, Martin Wieland and Andrea Zaghini, (2011), "The impact of sovereign credit risk on bank funding conditions", Bank for International Settlements, CGFS Paper No. 43 
Reinhart, Carmen and Kenneth Rogoff, (2008a), "Is the 2007 U.S. Sub-Prime Financial Crisis So Different? An International Historical Comparison", NBER Working Paper No. 13761, January 2008

Reinhart, Carmen and Kenneth Rogoff, (2008b), "Banking Crises: An Equal Opportunity Menace”, NBER Working Paper No. 14587, December 2008 
ANNEX 1

Major International Banks: Total Assets, Risk Weighted Assets and Total Common Equity at the end of $2011{ }^{(1)}$

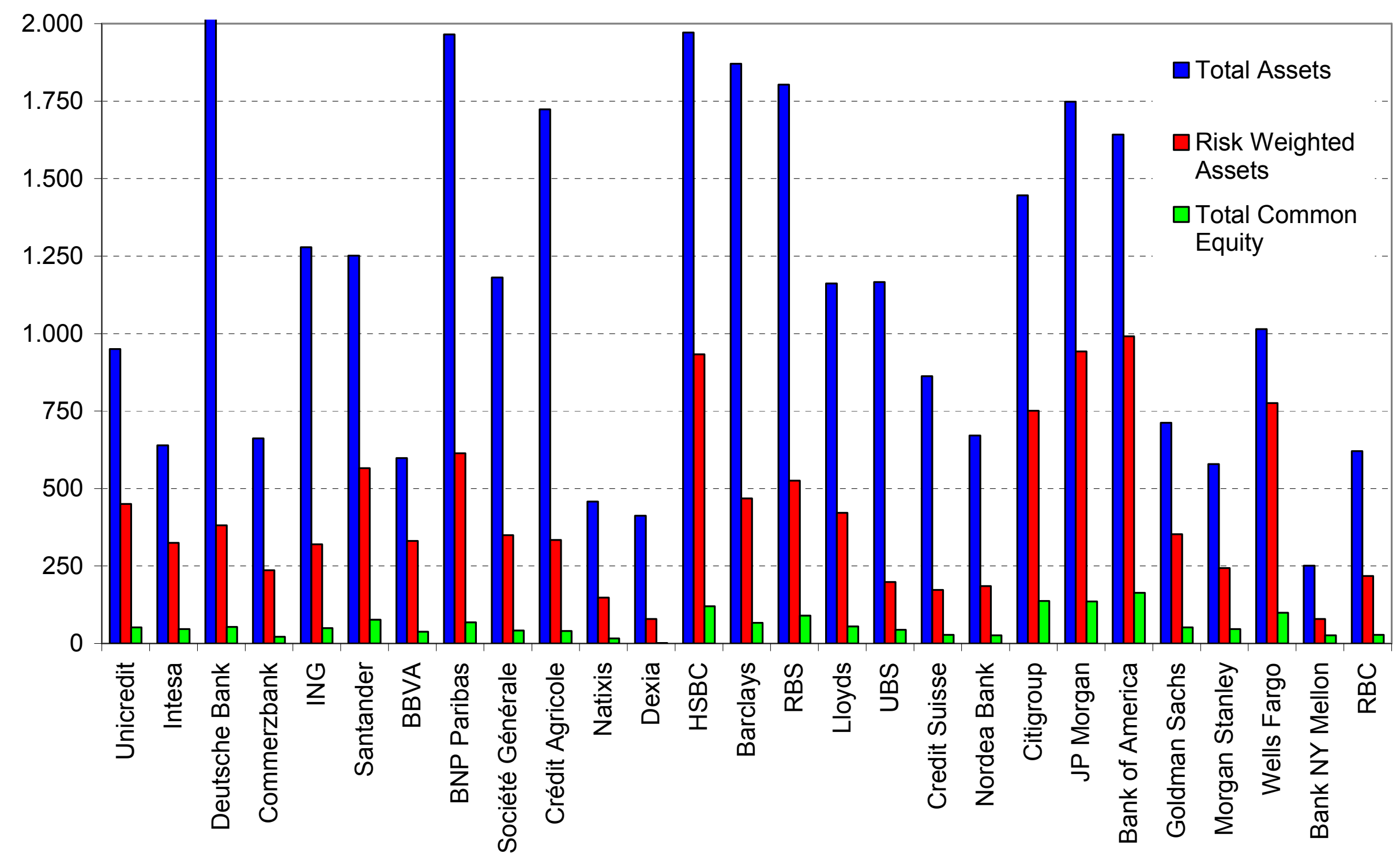

Source: Authors' calculations on Bloomberg and Datastream Data.

(1) Where not available, data from the preceding quarter are considered. 


\section{ANNEX 2}

\section{The Database}

\section{The data}

The balance sheets' data, shown in charts 2 to 12, are taken from Bloomberg.

The time horizon is 1999 Q1 : 2011 Q4.

Banks data are not consolidated backwards with the data of merged/acquired banks.

Balance sheet data are observed at quarterly frequency, however the reference period of every datum is yearly (with every change to the preceding datum to be considered as the yoy variation). Quarterly flows data are presented on a yearly basis calculating the trailing sum of the last four quarters data. Quarterly stocks data are averaged through the last four quarters.

All the indicators are built as ratios of two different balance sheet items. Then they are independent from the reference currency and are not affected by different orders of magnitude. In any quarter, indicators show the ratio between two annualized balance sheet items.

\section{Estimation procedure of quarterly data}

Quarterly data for banks providing only semi-annual data (BNP Paribas, Société Générale, Crédit Agricole, Natixis, HSBC, Barclays, Royal Bank of Scotland and Lloyds Banking Group) are estimated.

Quarterly stocks data are calculated under the assumption of a constant accumulation through time. Quarterly flows data are estimated on the basis of an autoregressive procedure. For each variable, quarterly data (Q) from the rest of the sample (19 banks) were collected. Given that

$$
S_{t}^{i}=Q_{t}^{i}+Q_{t-1}^{i}
$$

we built a semi-annual data series for this sub-group of banks, with semesters ending at the second and fourth quarter of the year $\left(\mathrm{Q}_{i t}\right)$. Then we run a linear regression - for the first and third quarter of every year of the sample - on the following equation:

$$
Q_{t-1}^{i}=\alpha_{0} S_{t}^{i}+\alpha_{1} S_{t-2}^{i}+\alpha_{2} S_{t-4}^{i}
$$


The constant parameter was forced to zero. Usually the R-squared coefficient was above $90 \%$ for every quarter considered and every variable. Applying the estimated parameters $-\hat{\alpha}_{i}$ of equation (2) - to the semi-annual data, we managed to estimate $\hat{Q}_{t-1}^{i}$ for every variable and every bank providing only semi-annual data. With equation (1), we completed our quarterly data estimation.

With specification (2) we connect every quarterly result with the fluctuation of the same variable through time in the rest of the sample (where quarterly data were available), provided rest-of-thesample results are the best predictors of intra-semester results for the banks with only semi-annual data. 


\section{ANNEX 3}

\section{Operating income decomposition}

Net Revenues (Total Income) to Total Operating Costs Ratio. Total Income is then decomposed into: Net Interest Income (blue area), Commissions and Fees (Green), Trading and Account Profits (Red) and Other Income (Yellow). Quarterly data (annualized via the trailing sum of the preceding 4 quarters). Banks are shown with the same order as Table 1.

BNP Paribas

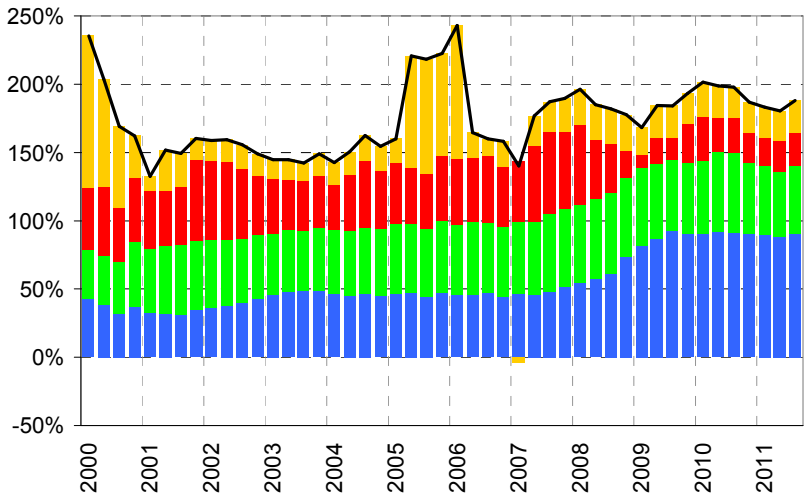

Deutsche Bank

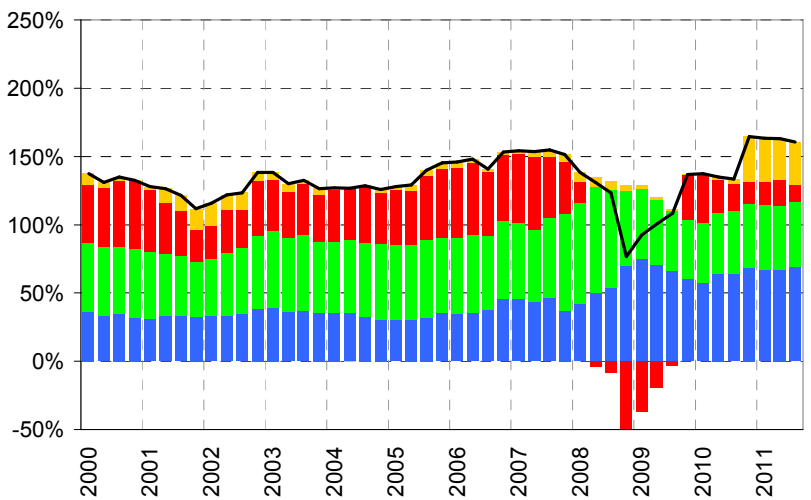

Royal Bank of Scotland

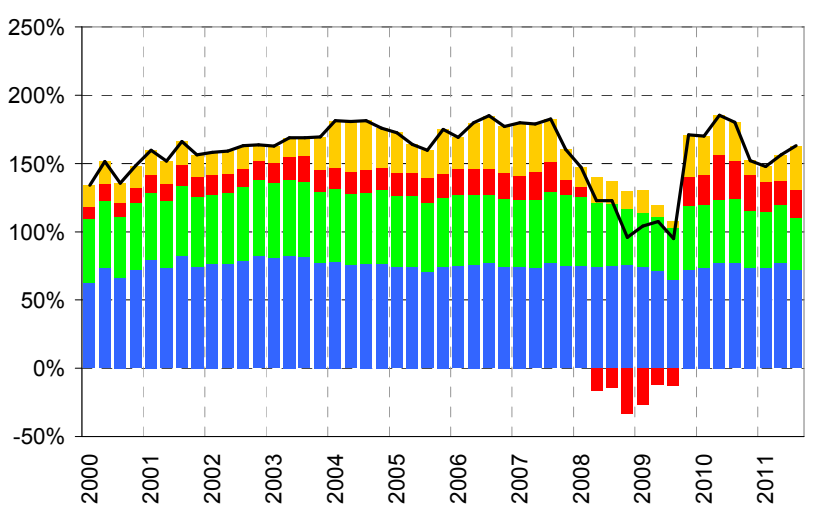

HSBC

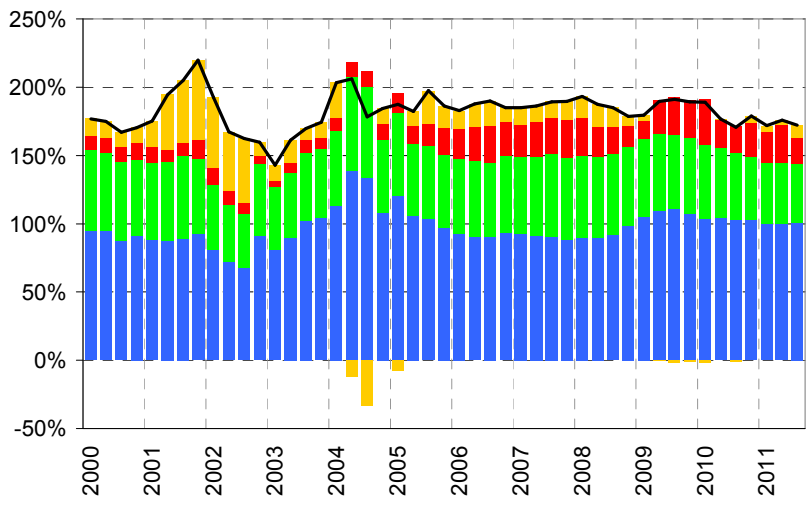

Barclays

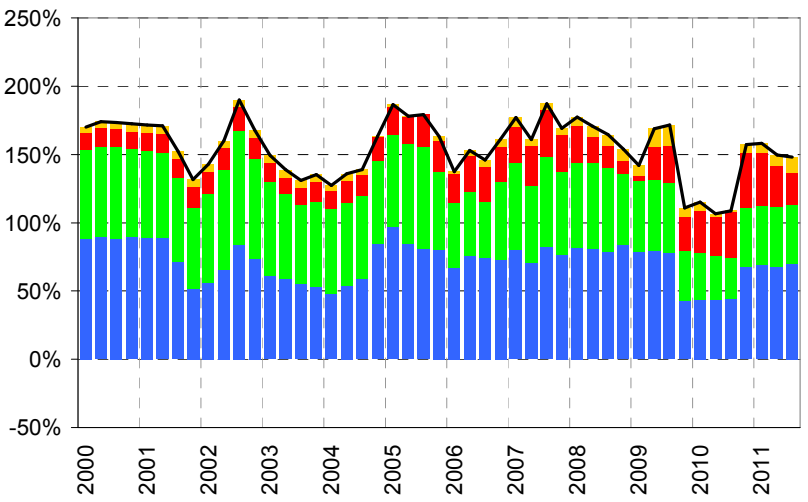

Bank of America

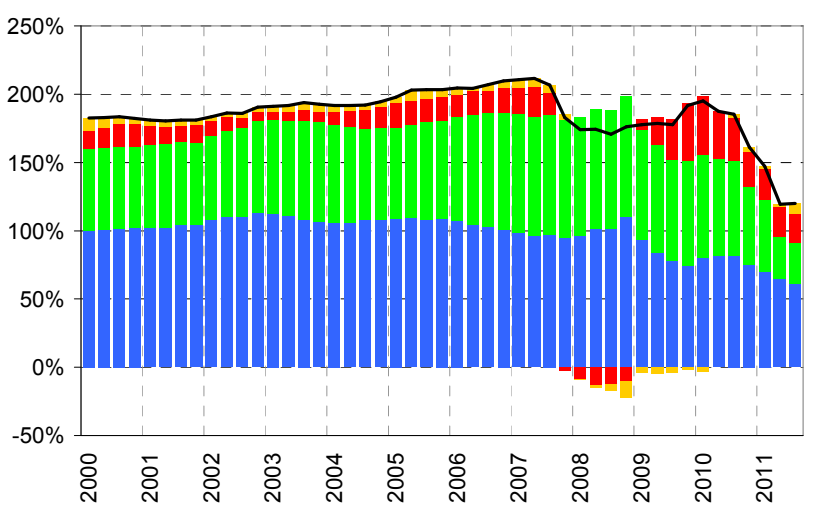



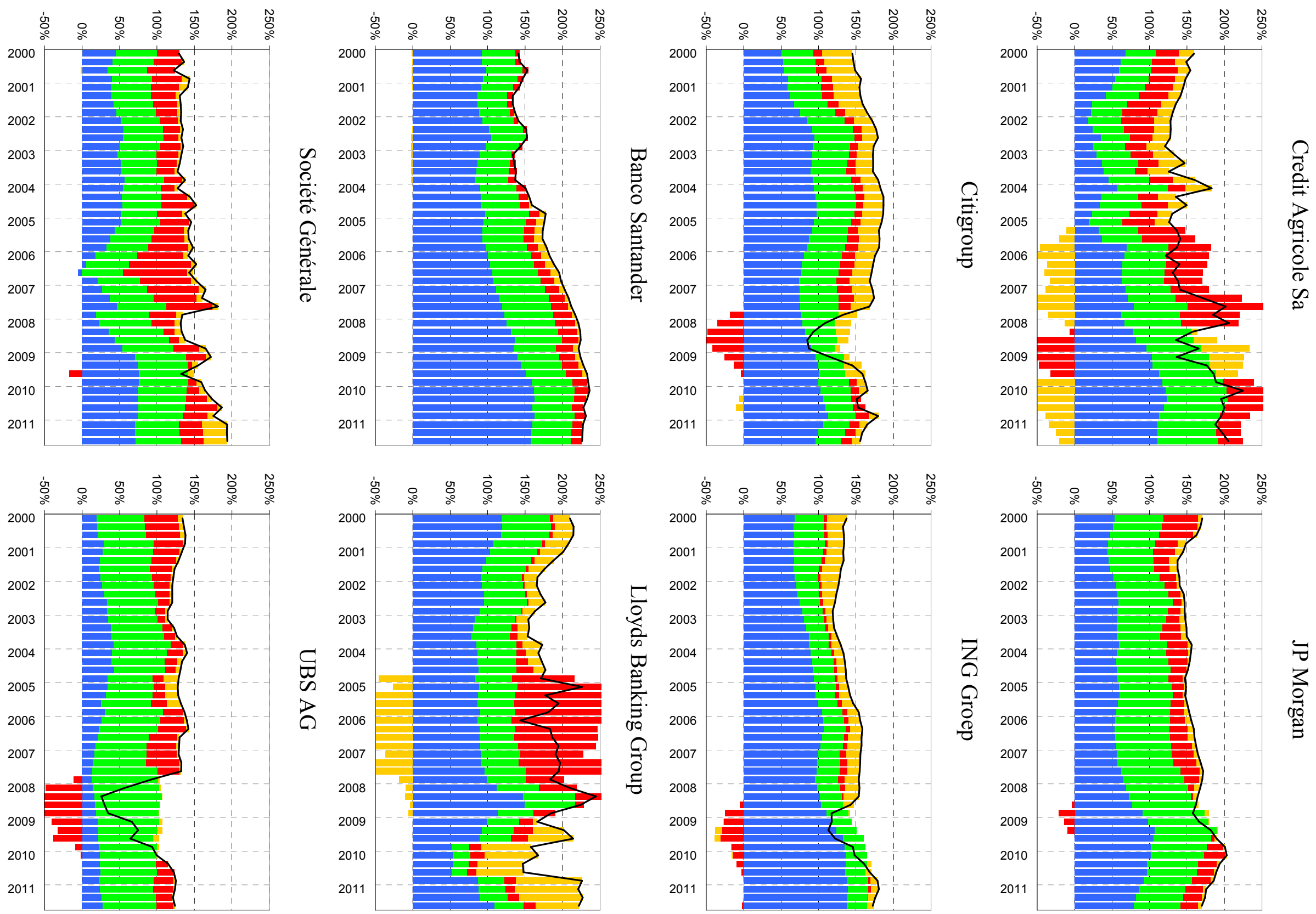

7
3
0
0
0
0
0
0 

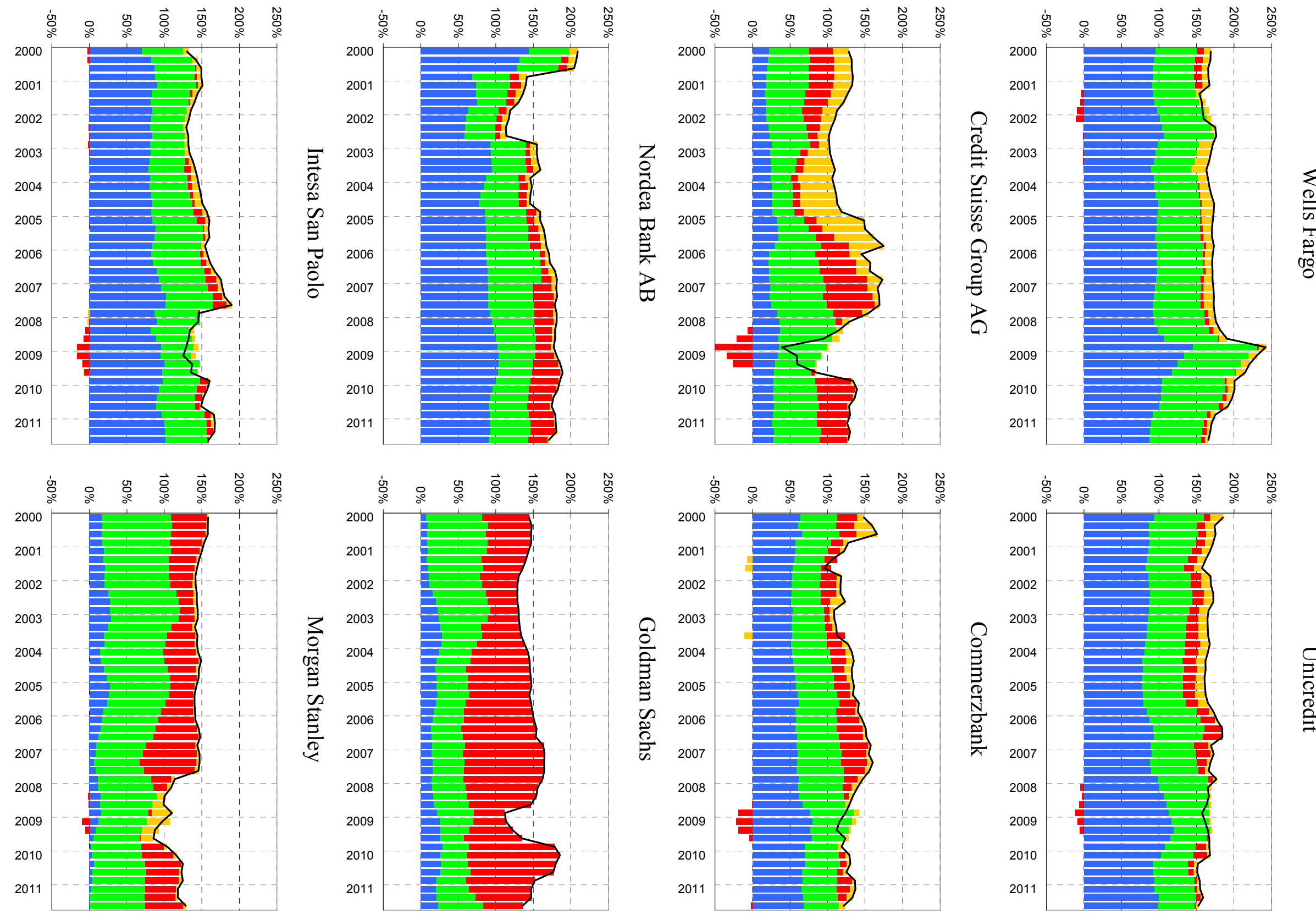

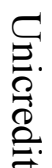


BBVA

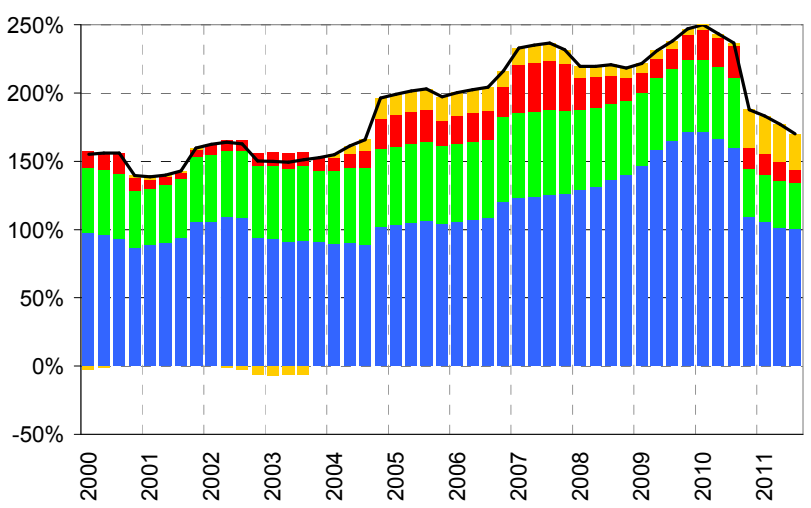

Royal Bank of Canada

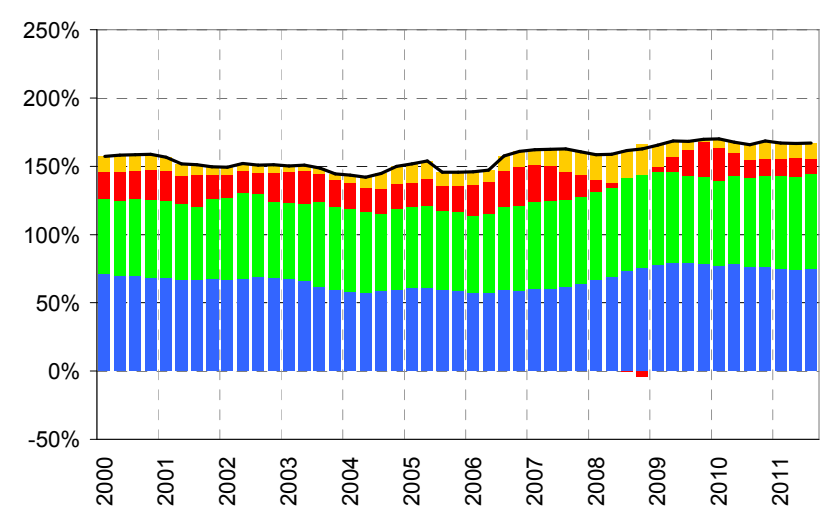

Bank of New York Mellon

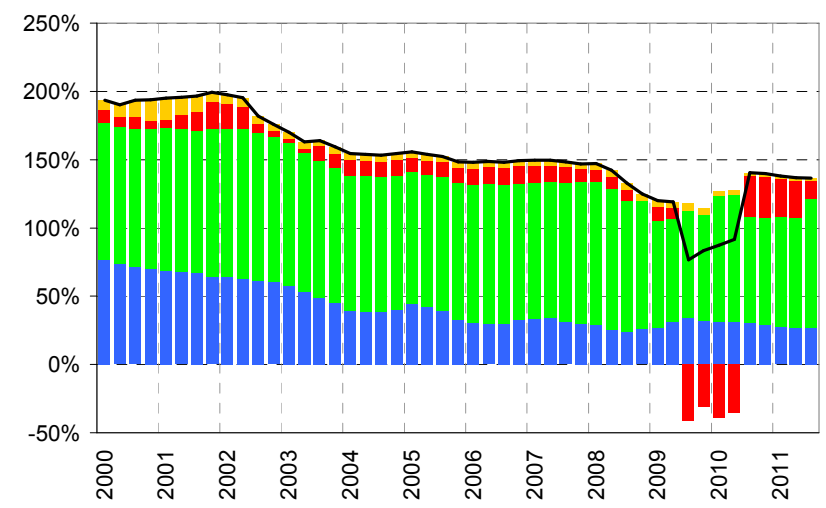

Source: Authors' calculations on Bloomberg data
Dexia

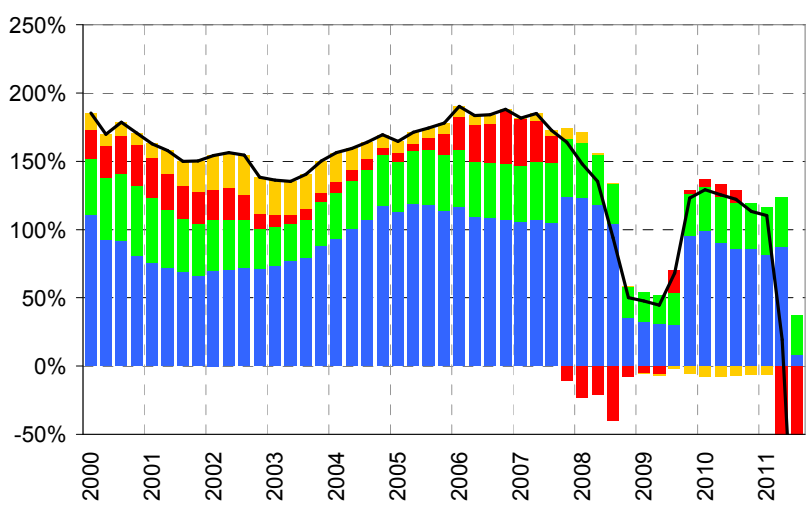

Natixis

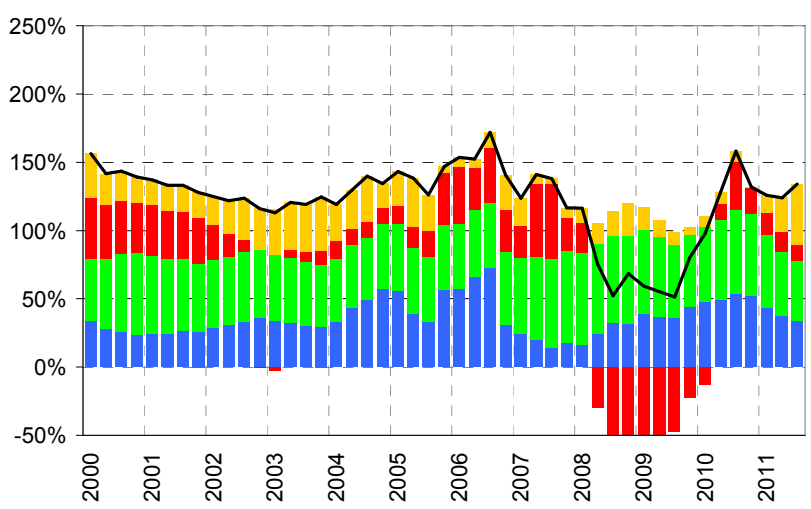

